\title{
Global model simulations of air pollution during the 2003 European heat wave
}

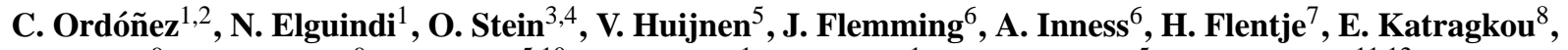 \\ P. Moinat ${ }^{9}$, V.-H. Peuch ${ }^{9}$, A. Segers ${ }^{5,10}$, V. Thouret ${ }^{1}$, G. Athier ${ }^{1}$, M. van Weele ${ }^{5}$, C. S. Zerefos ${ }^{11,12}$, J.-P. Cammas ${ }^{1}$, and \\ M. G. Schultz ${ }^{3}$ \\ ${ }^{1}$ Laboratoire d'Aérologie, UMR5560, CNRS and Université de Toulouse, Toulouse, France \\ ${ }^{2}$ Met Office, Atmospheric Dispersion Group, Exeter, UK \\ ${ }^{3}$ FZ Jülich, Institute for Chemistry and Dynamics of the Geosphere - 2: Troposphere, Jülich, Germany \\ ${ }^{4}$ Max Planck Institute for Meteorology, Hamburg, Germany \\ ${ }^{5}$ Royal Netherlands Meteorological Institute (KNMI), De Bilt, The Netherlands \\ ${ }^{6}$ European Centre for Medium-Range Weather Forecasts (ECMWF), Reading, UK \\ ${ }^{7}$ Deutscher Wetterdienst (DWD), Observatorium Hohenpeißenberg, Germany \\ ${ }^{8}$ Laboratory of Atmospheric Physics, Aristotle University of Thessaloniki, Thessaloniki, Greece \\ ${ }^{9}$ Météo-France, Centre National de Recherches Météorologiques, Toulouse, France \\ ${ }^{10}$ TNO Built Environment and Geosciences, Department of Air Quality and Climate, Utrecht, The Netherlands \\ ${ }^{11}$ Laboratory of Climatology and Atmospheric Environment, Faculty of Geology and Geoenvironment, \\ University of Athens, Greece \\ ${ }^{12}$ Atmospheric Environment Division, Biomedical Research Foundation of the Academy of Athens, Greece
}

Received: 14 July 2009 - Published in Atmos. Chem. Phys. Discuss.: 7 August 2009

Revised: 4 January 2010 - Accepted: 6 January 2010 - Published: 26 January 2010

\begin{abstract}
Three global Chemistry Transport Models MOZART, MOCAGE, and TM5 - as well as MOZART coupled to the IFS meteorological model including assimilation of ozone $\left(\mathrm{O}_{3}\right)$ and carbon monoxide $(\mathrm{CO})$ satellite column retrievals, have been compared to surface measurements and MOZAIC vertical profiles in the troposphere over Western/Central Europe for summer 2003. The models reproduce the meteorological features and enhancement of pollution during the period 2-14 August, but not fully the ozone and $\mathrm{CO}$ mixing ratios measured during that episode. Modified normalised mean biases are around $-25 \%$ (except $\sim 5 \%$ for MOCAGE) in the case of ozone and from $-80 \%$ to $-30 \%$ for $\mathrm{CO}$ in the boundary layer above Frankfurt. The coupling and assimilation of CO columns from MOPITT overcomes some of the deficiencies in the treatment of transport, chemistry and emissions in MOZART, reducing the negative biases to around $20 \%$. The high reactivity and small dry deposition velocities in MOCAGE seem to be responsible for the overestimation of $\mathrm{O}_{3}$ in this model. Results from sensitivity simulations indicate that an increase of the horizontal
\end{abstract}

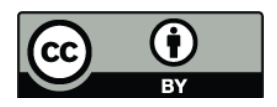

Correspondence to: C. Ordóñez (carlos.ordonez@metoffice.gov.uk) resolution to around $1^{\circ} \times 1^{\circ}$ and potential uncertainties in European anthropogenic emissions or in long-range transport of pollution cannot completely account for the underestimation of $\mathrm{CO}$ and $\mathrm{O}_{3}$ found for most models. A process-oriented TM5 sensitivity simulation where soil wetness was reduced results in a decrease in dry deposition fluxes and a subsequent ozone increase larger than the ozone changes due to the previous sensitivity runs. However this latest simulation still underestimates ozone during the heat wave and overestimates it outside that period. Most probably, a combination of the mentioned factors together with underrepresented biogenic emissions in the models, uncertainties in the modelling of vertical/horizontal transport processes in the proximity of the boundary layer as well as limitations of the chemistry schemes are responsible for the underestimation of ozone (overestimation in the case of MOCAGE) and CO found in the models during this extreme pollution event.

\section{Introduction}

Summer 2003 was extremely dry and warm in Europe. Based on a reconstruction of monthly and seasonal temperature fields for European land areas back to 1500, Luterbacher

Published by Copernicus Publications on behalf of the European Geosciences Union. 
et al. (2004) concluded that summer 2003 was very likely warmer than any other summer during the last 500 years. In a large area around central Europe the mean summer (JJA) temperatures exceeded the $1961-1990$ mean by $3{ }^{\circ} \mathrm{C}$, corresponding to an excess of up to 5 standard deviations of the summer means in that period (Schär et al., 2004). Under the assumption of unmitigated greenhouse gas emissions in the future, summer 2003 temperatures could bear a close resemblance with climate change scenarios for the late XXI century (Beniston, 2004; Schär et al., 2004; Stott et al., 2004).

Trigo et al. (2005) analysed the spatial and temporal evolution of the summer heat wave at sub-monthly scale and found the strongest temperature and geopotential anomalies between the 1st and the 15th of August 2003. Tressol et al. (2008) showed that MOZAIC aircraft profiles above Frankfurt in July-August 2003 present strong temperature anomalies (exceeding $4{ }^{\circ} \mathrm{C}$ ) throughout the lower troposphere with respect to an 11-year MOZAIC climatology. Similarly to Trigo et al. (2005), the highest positive anomalies of temperature and the strongest negative anomalies of both wind speed and relative humidity in the MOZAIC profiles were found for the period 2-14 August 2003, which they defined as the heat wave. Smaller anomalies were found for the periods before (16-31 July 2003) and after (16-31 August 2003) the heat wave. The analysis of simulations carried out with the Lagrangian particle dispersion model FLEXPART indicate extended residence time of air parcels in the European boundary layer (Solberg et al., 2008), suppressed long-range transport in the mid- to lower troposphere and enhanced southern origin of air masses for all tropospheric levels during the heat wave period (Tressol et al., 2008). The unprecedented 2003 heat wave and in particular the first half of August had a major impact on excessive mortality rates throughout Europe. France suffered the largest burden of this public health catastrophe with approximately 15000 excess deaths (e.g. WHO, 2004; Trigo et al., 2005, and references therein). Trigo et al. (2005) have shown that the geographical pattern of the temperature anomaly matched well the mortality rates in France during the period 1-15 August 2003, although air quality as well as the specific sensitivities to high temperatures (particularly at night) of the populations living in the North or in the South of France also play a role. Filleul et al. (2006) confirmed that ozone $\left(\mathrm{O}_{3}\right)$ levels had a non-negligible impact on public health in urban areas of France during the August 2003 heat wave, and also found that the relative contribution of ozone and temperature to the high mortality was heterogeneous among cities according to local characteristics.

The described summer 2003 led to exceptionally longlasting and spatially extensive periods of high ozone in Europe, mainly during the first half of August, as observed at the European Environment Information and Observation Network (EIONET/AIRBASE) supported by the European Environmental Agency (Fiala et al., 2003). Exceedance of the information threshold (hourly average concentrations of
$180 \mu \mathrm{g} / \mathrm{m}^{3}$ ) occurred in 23 of the 31 countries reporting and at about $68 \%$ of all stations (1220 stations). The spatial distribution of those exceedances was much more widespread in summer 2003 than in previous summers, and it covered mainly South Western Germany, Switzerland, Northern and South Eastern France, Belgium, Northern and Central Italy and Central Spain as well as Southern England and The Netherlands. An analysis of ozone trends in Switzerland during the reference period 1992-2002 indicates that the $\sim 15 \mathrm{ppb}$ higher than usual daily $\mathrm{O}_{3}$ maxima registered during summer 2003 can be explained by elevated afternoon temperatures, absence of frontal passages and high morning global radiation (Ordóñez et al., 2005). During the first half of August 2003, various processes such as stagnation, photochemistry or forest fires led to unusually high particle concentrations and optical thicknesses (Hodzic et al., 2006). In particular, the presence of elevated smoke layers over Europe decreased photolysis rates at surface by 10 to $30 \%$, which could have inhibited regional ozone production, but the heating caused by such aerosols might also have contributed to reinforcing the atmospheric stability and to maintaining the heat wave conditions during summer 2003 (Hodzic et al., 2007). Lee et al. (2006) found enhanced levels of carbon monoxide (CO) and photochemical products such as $\mathrm{O}_{3}$, formaldehyde (HCHO) and acetone, from 6 to 10 August during the TORCH campaign in the UK. They emphasised that the entrainment of air from the residual layer aloft, polluted on a regional scale, controlled the abundance of anthropogenic volatile organic compounds (VOCs) and photochemical products. In addition, increased temperatures and solar radiation favoured biogenic emissions of isoprene as observed in Southeast England (Lee et al., 2006) and South Eastern France (Solberg et al., 2008), with a potential for enhanced ozone chemistry in the boundary layer. The high levels of atmospheric pollutants had important consequences for human health. Stedman (2004) estimated that of the 2045 excess deaths in England and Wales for the period 4-13 August 2003 compared to the average for that time of the year, between 423 and 769 deaths were associated with the elevated ambient ozone and PM10 concentrations. Fischer et al. (2004) found that of an excess of 1000-1400 deaths in The Netherlands during summer 2003 compared to an average summer, 400-600 deaths were ozone- and PM10-related.

Vautard et al. (2005) modelled European pollution during the first half of August 2003. They performed a number of sensitivity runs with the regional chemistry transport model (CTM) CHIMERE (only gas-phase) to account for the exceptional conditions of that summer. Compared to the three CTMs used in the present study (MOZART, TM5 and MOCAGE), CHIMERE has higher horizontal resolution and presents a more comprehensive chemical mechanism that is only similar, as VOCs and their oxidation products are concerned, to the one used in MOCAGE. Low vegetation with superficial roots probably underwent water deficit during spring-summer 2003, which is expected to strongly 
decrease stomatal ozone uptake. Since such dependence was not taken into account in CHIMERE, in their reference simulation they doubled the standard surface resistances to dry deposition (Wesely, 1989) for some land use types. The simulated ozone concentrations compared well with surface observations from European monitoring stations. Another simulation with standard dry deposition and anthropogenic VOC emissions increased by $30 \%$, in order to account for the extra evaporation of anthropogenic VOCs by the exceptional temperatures, produced nearly identical results. A set of sensitivity model runs with the Oslo CTM2 at spectral resolution $\mathrm{T} 42\left(2.8^{\circ} \times 2.8^{\circ}\right)$ also proved that dry deposition was a critical parameter for surface ozone during that period (Solberg et al., 2008). They turned off dry deposition over a large fraction of Europe yielding an increase in peak ozone levels of more than $20 \%$. As they pointed out, turning off dry deposition is not physically realistic because there is a significant non-stomatal deposition flux, but it shows the upper limit of the influence of this process.

Aerosol modelling of the same episode with the CHIMERE model could not reproduce the intense aerosol optical thickness (AOT) peaks on 3-4 August over Portugal and 5-6 August over Benelux (Hodzic et al., 2006). They showed that a parameterisation of injection heights is needed to correctly simulate the advection of smoke particles emitted from forest fires in Portugal over Northern and Central Europe. An improved simulation including a MODIS-derived daily smoke emission inventory as well as the injection altitude of smoke particles resulted in a significantly enhanced simulation of the observed aerosol concentrations and optical properties (Hodzic et al., 2007). Tressol et al. (2008) showed that layers with enhanced $\mathrm{CO}$ and total odd nitrogen $\left(\mathrm{NO}_{\mathrm{y}}\right)$ mixing ratios, advected from Portugal, were crossed by the MOZAIC aircraft in the free troposphere over Frankfurt. They concluded that during the period 16 July-31 August, European anthropogenic emissions present the strongest contribution to the measured $\mathrm{CO}$ levels in the lower troposphere (near 30\%), followed by Portuguese forest fires. The contribution of biomass burning reaches $35 \%$ between 6 and 10 August 2003.

Earlier regional and global CTM simulations of ozone for the 2003 European heat wave have focused on the distribution of surface $\mathrm{O}_{3}$ (e.g. Vautard et al., 2005; Guerova and Jones, 2007; Solberg et al., 2008). This study presents global model simulations for that period carried out within the Global Reactive Gases (GRG) subproject of GEMS (Global Earth-system Monitoring using Space and in-situ data) and comparisons with MOZAIC vertical profiles over three European airports. A main task of the global CTMs used in GEMS is to provide realistic tropospheric profiles as initial and boundary conditions for regional air quality models, which cover Europe at higher horizontal resolutions (currently between $0.1^{\circ}$ and $0.5^{\circ}$ ) and have more comprehensive VOC oxidation schemes. The objective of this paper is to show the first evaluation of modelled tropospheric $\mathrm{O}_{3}$ and
CO profiles, with focus on the lower troposphere, for summer 2003. A number of sensitivity simulations are analysed to estimate the contribution of different processes to the observed ozone and $\mathrm{CO}$ mixing ratio profiles.

\section{Models, data and methods}

\subsection{Description of the models}

The GRG subproject of GEMS aims at developing a pre-operational data assimilation system for chemically reactive gases within the ECMWF's Integrated Forecasting System (IFS) (http://www.ecmwf.int/research/ifsdocs/CY31r1/index.html) capable of providing global products for the troposphere and stratosphere on a daily basis (Hollingsworth et al., 2008). This assimilation/forecast system also provides initial and boundary conditions for regional air-quality forecast systems. Since it is premature to introduce a full chemistry representation in the IFS model, the OASIS4 software (Redler et al., 2009) has been used to implement a two-way coupling of the IFS model to three CTMs: MOCAGE (Josse et al., 2004; Bousserez et al., 2007), MOZART-3 (Horowitz et al., 2003; Kinnison et al., 2007), and TM5 (Krol et al., 2005). These models have performed a multi-year reanalysis of the atmospheric chemical composition, including the period of the 2003 European heat wave. Results from MOCAGE, MOZART-3, and TM5 (version TM5-KNMI-cy3-GEMS-V3) stand-alone runs as well as from the coupled IFS/MOZART system are shown here. The use of multiple models provides an indication of the uncertainty in the chemical modelling, as the three systems differ in resolutions and physico-chemical parameterisations within the current state-of-the-art in global chemistry and transport modelling.

The CTMs used in GEMS-GRG are driven by meteorological fields interpolated in space and time from an ECMWF reanalysis for 2003 based on the ERA-40 setup (Uppala et al., 2005). The meteorological input is 3-hourly for TM5 and 6-hourly for MOZART and MOCAGE. In the case of TM5, horizontal and vertical wind fields are derived from mass fluxes through the grid cell boundaries (see details in Krol et al., 2005, and references therein). Hourly horizontal winds on MOCAGE and MOZART grids are obtained by interpolation from ECMWF 6-hourly analyses. Vertical wind in MOCAGE is calculated from the horizontal components by imposing mass conservation for each atmospheric column with a zero vertical velocity boundary condition at the top of the atmosphere. Vertical velocities in MOZART are derived from the divergence of the horizontal velocity fields, using a flux form semi-Lagrangian transport scheme based on Lin and Rood (1996) which allows for tracer mass conservation. The CTMs use monthly emissions at a resolution of $0.5^{\circ} \times 0.5^{\circ}$ interpolated to their own 
coarser grid. Anthropogenic emissions are based on emission data sets for the year 2000 from the RETRO project (http://retro.enes.org). Monthly wildfire emissions are taken from the GFEDv2 data set (van der Werf et al., 2006). This product includes explicit information on fire emissions for the year 2003, based on analysis of MODIS fire data and fuel load modelling with the CASA model (Randerson et al., 2005, and references therein). In a more recent GFEDv2.1 dataset, emission estimates for the 2001-2005 period are also available with an 8-day time step (Randerson et al., 2007), but such a product was still not available at the time when the model simulations presented here were set up. Biogenic emissions from a decadal mean data set of Lathière et al. (2005) are included, and they are complemented by emissions from GEIA 1985 (http://www.geiacenter.org/). Emissions are injected in the lowest model level in MOZART and in the two lowest levels in TM5, with $40 \%$ in the first and $60 \%$ in the second level, on a monthly basis. In the case of MOCAGE emissions are distributed in the eight lowest levels of the model, which correspond on average to a layer of $600 \mathrm{~m}$, with quantities injected logarithmically decreasing with altitude, in order to avoid too strong vertical gradients, as proposed and evaluated in Josse et al. (2004). Aircraft emissions in TM5 are taken from the ANCAT dataset (Gardner et al., 1997), increased by a year-dependent scaling factor, and in MOZART from Horowitz et al. (2003). In MOCAGE, aircraft emissions from the POLINAT project (Schmitt and Brunner, 1997) have been considered.

The version of the coupled-assimilation system used here consists of IFS coupled to MOZART. IFS supplies meteorological data at 1-h temporal resolution to the coupled CTM. IFS has been extended to simulate the transport of the main species considered here $\left(\mathrm{O}_{3}\right.$ and $\left.\mathrm{CO}\right)$ as well as of any other chemical tracers of interest represented in the CTM. The CTM provides to IFS initial conditions for these tracers and 3-D tendency fields accounting for source and sink processes not included in IFS, such as chemical conversion, emissions and deposition. Various sources of satellite data have been explored in GEMS-GRG to optimally constrain atmospheric fields of some reactive gases within a four dimensional variational (4D-Var) data assimilation system (Rabier et al., 2000). The configuration of the coupled IFS/MOZART system used in this study assimilates $\mathrm{CO}$ column data from the MOPITT instrument and $\mathrm{O}_{3}$ data from SCIAMACHY, MIPAS, GOME and SBUV. CO and $\mathrm{O}_{3}$ modelled fields are constrained by observations from the mentioned satellite instruments within each data assimilation window. The changes in concentration due to these observational constraints can then be fed back to the coupled CTM at the start of the next assimilation window. See further details on the coupling in Flemming et al. (2009) and on the data assimilation in Innes et al. (2009). It should be noted that the 2003 reanalysis used in this paper is previous to the Integrated GEMS Reanalysis (http://gems-test.ecmwf. int/d/products/integrated/reanalysis/), which covers the pe- riod 2003-2007 and assimilates satellite data to constrain ozone, carbon monoxide, methane, carbon dioxide, and aerosol.

A brief summary of the models used can be found in Table 1. The different simulations performed with these models are explained in Sect. 2.1.1 and summarised in Table 2.

\subsubsection{Model simulations}

All model configurations used in this study have 60 hybrid vertical levels from the surface to $\sim 0.1 \mathrm{hPa}$. The MOCAGE, MOZART-3 and TM5 stand-alone base runs were initially performed at horizontal resolutions of $2^{\circ} \times 2^{\circ}$, $1.875^{\circ} \times 1.895^{\circ}$ and $3^{\circ} \times 2^{\circ}$, respectively. The coupled IFS/MOZART system was run, without and with data assimilation, with the IFS at T159 truncation in spectral space (with corresponding reduced Gaussian grid of about $125 \mathrm{~km} \times 125 \mathrm{~km}$ ) and MOZART on a $1.875^{\circ} \times 1.895^{\circ}$ regular lat/lon grid. Hereafter these global simulations are named MOCAGE, MOZART, TM5-HWGL, COUPL and COUPLASSIM, respectively. A number of sensitivity runs have been performed to investigate the impact of different processes on the ozone and $\mathrm{CO}$ concentrations:

1. Sensitivity to higher horizontal resolution. Two simulations are available:

- MOZART t106: MOZART-3 stand-alone run at an improved horizontal resolution of $1.125^{\circ} \times 1.125^{\circ}$.

- TM5-HWHR: Same run as TM5-HWGL, but with output fields at $1^{\circ} \times 1^{\circ}$ horizontal resolution over the European domain. This improved horizontal resolution results from the two-way nesting zoom capability of TM5 as described in Krol et al. (2005). Since other sensitivity runs of TM5 will be evaluated at $1^{\circ} \times 1^{\circ}$ they will be compared with TM5HWHR, which will be considered as a control run. All TM5 sensitivity simulations and MOZART t106 were run for the 3-month period June-August 2003.

2. Sensitivity to anthropogenic emissions in Europe and outside Europe. Two simulations will be compared with TM5-HWHR to investigate the impact of the emission inventories, the recirculation of pollution in Europe and the transboundary transport on the pollution levels during and outside the heat wave period:

- TM5-HWEE: As TM5-HWHR, but with 25\% extra anthropogenic emissions of nitrogen oxides $\left(\mathrm{NO}_{\mathrm{x}}\right)$, $\mathrm{CO}$, and non-methane VOCs (NMVOCs) over Europe.

- TM5-HWEN: As TM5-HWHR, but without anthropogenic emissions of $\mathrm{NO}_{\mathrm{x}}, \mathrm{CO}$, and NMVOCs outside Europe. 
Table 1. Brief summary of the models used in this analysis.

\begin{tabular}{|c|c|c|c|c|}
\hline & MOZART-3 & TM5 & MOCAGE & IFS/MOZART $^{(1)}$ \\
\hline Institution & MPI Meteorology & KNMI & Météo-France & ECMWF \\
\hline Contact author & Olaf Stein & $\begin{array}{l}\text { Vincent Huijnen \& Michiel van } \\
\text { Weele }\end{array}$ & $\begin{array}{l}\text { Philippe Moinat \& Vincent-Henri } \\
\text { Peuch }\end{array}$ & $\begin{array}{l}\text { Johannes Flemming \& Antje In- } \\
\text { ness }\end{array}$ \\
\hline Resolution & $\begin{array}{l}1.875^{\circ} \times 1.895^{\circ}(\mathrm{t} 63) \\
1.125^{\circ} \times 1.125^{\circ}(\mathrm{t} 106)\end{array}$ & $3^{\circ} \times 2^{\circ}\left(\right.$ with zoom to $\left.1^{\circ} \times 1^{\circ}\right)$ & $2^{\circ} \times 2^{\circ}$ & $\begin{array}{l}\text { IFS t159 }(\sim 125 \mathrm{~km} \times 125 \mathrm{~km}) \text { cou- } \\
\text { pled to MOZART } 1.875^{\circ} \times 1.895^{\circ}\end{array}$ \\
\hline Vertical levels & 60 & 60 & 60 & 60 \\
\hline Meteorology & ECMWF (6-h) & ECMWF (3-h) & ECMWF (6-h) & ECMWF (1-h), on-line \\
\hline $\begin{array}{l}\text { Tropospheric } \\
\text { chemistry }\end{array}$ & $\begin{array}{l}\text { Updated from MOZART-2 } \\
\text { (Horowitz et al., 2003) with exten- } \\
\text { sion to the stratosphere (Kinnison } \\
\text { et al., 2007) } \\
110 \text { gas species } \\
208 \text { gas-phase reactions } \\
71 \text { photolytic reactions }\end{array}$ & $\begin{array}{l}\text { Adapted from CBM4 (Houweling } \\
\text { et al., 1998) } \\
55 \text { gas species ( } 39 \text { advected) } \\
\text { Aerosols included } \\
\text { Photolysis from Williams et } \\
\text { al. (2006) }\end{array}$ & $\begin{array}{l}\text { RACMOBUS, combining RACM } \\
\text { scheme (Stockwell et al., 1997) } \\
\text { for troposphere and REPROBUS } \\
\text { (Lefèvre et al., 1994) for strato- } \\
\text { sphere } \\
118 \text { species and } 350 \text { reactions } \\
\text { Off-line photolysis (Madronich } \\
\text { and Flocke, 1998), but impact of } \\
\text { clouds calculated on-line }\end{array}$ & $\begin{array}{l}\text { MOZART chemistry, with data as- } \\
\text { sim. for } \mathrm{CO} \text { and } \mathrm{O}_{3}\end{array}$ \\
\hline Advection & Lin and Rood (1996) & $\begin{array}{l}\text { Russell and Lerner (1981) } \\
\text { Prather (1986) }\end{array}$ & Williamson and Rasch (1989) & Semi-Lagrangian scheme ${ }^{(2)}$ \\
\hline Convection & $\begin{array}{l}\text { Shallow and mid-level convection: } \\
\text { Hack (1994) } \\
\text { Deep convection: Zhang and Mac- } \\
\text { Farlane (1995) }\end{array}$ & Tiedtke (1989) & $\begin{array}{l}\text { Adapted from Bechtold et } \\
\text { al. (2001) }\end{array}$ & Bulk-mass flux scheme ${ }^{(2)}$ \\
\hline Vertical diffusion & Holtslag and Boville (1993) & $\begin{array}{l}\text { Holtslag and Moeng (1991) for } \\
\text { near surface, Louis (1979) for free } \\
\text { troposphere }\end{array}$ & Adapted from Louis (1979) & $\begin{array}{l}\text { Eddy diffusivity mass flux scheme } \\
\text { (2) }\end{array}$ \\
\hline Dry deposition & $\begin{array}{l}\text { Müller (1992) } \\
\text { Surface resistances from Wesely } \\
\text { (1989) }\end{array}$ & Ganzeveld et al. (1998) & $\begin{array}{l}\text { Based on Wesely (1989) using } \\
\text { "big-leaf" resistance approach but } \\
\text { with a refined treatment of stom- } \\
\text { atal resistance (Michou and Peuch, } \\
\text { 2002; Michou et al., 2004) }\end{array}$ & As for MOZART \\
\hline Wet deposition & Horowitz et al. (2003) & Guelle et al. (1998) & $\begin{array}{l}\text { Giorgi and Chameides (1986), } \\
\text { Mari et al. (2000) }\end{array}$ & As for MOZART \\
\hline Ref. & $\begin{array}{l}\text { Horowitz et al. (2003) } \\
\text { Kinnison et al. (2007) }\end{array}$ & Krol et al. (2005) & $\begin{array}{l}\text { Josse et al. (2004) } \\
\text { Bousserez et al. (2007) }\end{array}$ & $\begin{array}{l}\text { Flemming et al. (2009) } \\
\text { Innes et al. (2009) }\end{array}$ \\
\hline
\end{tabular}

(1) ECMWF's Integrated Forecast System (IFS) coupled to MOZART-3

(2) As described at http://www.ecmwf.int/research/ifsdocs/CY31r1/index.html

3. Sensitivity to the reduced dry deposition of $\mathrm{O}_{3}$ as a consequence of the dryness of the vegetation accumulated during spring and summer. One available simulation:

- TM5-HWDN: As TM5-HWHR, but decreasing the soil water stress to 0.1 .

4. Three sensitivity simulations were performed with MOCAGE to examine the impact of the initial conditions and of the very comprehensive chemistry scheme used in this model:

- MOCAGE-STD: Continuation of the MOCAGE base run on 10 July 2003, but with initial conditions characterised by lower background ozone in the troposphere.

- MOCAGE-VOCUT: As MOCAGE-STD, but with emissions and initial conditions of highly reactive VOCs (HC8, HC5, HCHO, OLI, OLT, TOL, XYL, CSL) set to 0 (see Stockwell et al., 1997, for details on these VOCs).
- MOCAGE-CUTALL: Equivalent to MOCAGEVOCUT, but with emissions of the other VOCs reduced by a factor of two.

5. Sensitivity to the frequency of the meteorological feedback in the CTMs. The stand-alone MOZART run (6-h meteorological input) will be compared to the following simulation:

- MOZART 1 h-met: MOZART forecast run with 1$\mathrm{h}$ meteorological feedback.

\subsection{Measurements}

\subsubsection{MOZAIC measurements}

The MOZAIC program (Measurements of Ozone, Water Vapour, Carbon Monoxide and Nitrogen Oxides by InService Airbus Aircraft) started in 1993 with the aim of building a valuable database of measurements to improve the knowledge of the chemical and physical processes in the troposphere and the lowermost stratosphere (Marenco et 
Table 2. Summary of the model simulations analysed.

\begin{tabular}{lll}
\hline Name & Horiz. Resol. & Details \\
\hline MOZART & $1.875^{\circ} \times 1.895^{\circ}$ & Stand-alone MOZART-3 base run \\
TM5-HWGL & $3^{\circ} \times 2^{\circ}$ & Stand-alone TM5 base run \\
MOCAGE & $2^{\circ} \times 2^{\circ}$ & Stand-alone MOCAGE base run \\
COUPL & see Table 1 & Coupled IFS/MOZART system \\
COUPL-ASSIM & see Table 1 & As COUPL but with data assimilation for CO and O 3 \\
MOZART t106 & $1.125^{\circ} \times 1.125^{\circ}$ & As MOZART but with improved horizontal resolution \\
TM5-HWHR & zoom to $1^{\circ} \times 1^{\circ}$ & As TM5-HWGL but with zoom over the European domain \\
TM5-HWEE & zoom to $1^{\circ} \times 1^{\circ}$ & As TM5-HWHR but with 25\% extra anthropogenic emissions over Europe \\
TM5-HWEN & zoom to $1^{\circ} \times 1^{\circ}$ & As TM5-HWHR but without anthropogenic emissions outside Europe \\
TM5-HWDN & zoom to $1^{\circ} \times 1^{\circ}$ & As TM5-HWHR but with soil water stress set to 0.1 \\
MOCAGE-STD & $2^{\circ} \times 2^{\circ}$ & As MOCAGE but initialisation with lower tropospheric background ozone \\
MOCAGE-VOCUT & $2^{\circ} \times 2^{\circ}$ & As MOCAGE-STD but with initial conditions and emissions of most reactive VOCs set to 0 \\
MOCAGE-CUTALL & $2^{\circ} \times 2^{\circ}$ & As MOCAGE-VOCUT but with emissions of the other VOCs reduced by a factor of 2 \\
MOZART 1h-met & $1.875^{\circ} \times 1.895^{\circ}$ & MOZART forecast run with 1h meteorological input \\
\hline
\end{tabular}

al., 1998). Measurements of ozone and water vapour have been operational since 1994 while $\mathrm{CO}$ and $\mathrm{NO}_{\mathrm{y}}$ measurements started at the end of 2001. The ozone analyser installed onboard each of the five MOZAIC aircraft is a dualbeam UV absorption instrument (Thermo-Electron, model 49-103). The measurement accuracy for individual (4s) measurements was estimated to be $\pm[2 \mathrm{ppb}+2 \%]$, although better in-flight performance has been observed (Thouret et al., 1998). The MOZAIC CO analyser is an improved version of a commercial Model 48CTL from Thermo Environmental Instruments, based on the Gas Filter Correlation principle of infrared absorption by the $4.67 \mu \mathrm{m}$ fundamental vibration-rotation band of $\mathrm{CO}$. The analyser has achieved a measurement precision of $\pm[5 \mathrm{ppb} \pm 5 \%]$ for $30 \mathrm{~s}$ integration time (Nedelec et al., 2003). More details on the $\mathrm{O}_{3}$, $\mathrm{CO}$ and $\mathrm{NO}_{\mathrm{y}}$ measurements performed during the MOZAIC program can be found in Thouret et al. (1998), Nedelec et al. (2003) and Volz-Thomas et al. (2005), respectively. For the most updated information on the program, refer to http://mozaic.aero.obs-mip.fr.

In the present study, measurements of $\mathrm{O}_{3}, \mathrm{CO}$, temperature, wind and relative humidity during MOZAIC ascent and descent vertical profiles above European airports in July August 2003 are used. Three airports with relatively good frequency of observations during the period of analysis have been selected: Paris $\left(2.56^{\circ} \mathrm{E}, 49.00^{\circ} \mathrm{N}\right)$, Frankfurt $\left(8.56^{\circ} \mathrm{E}\right.$, $\left.50.03^{\circ} \mathrm{N}\right)$, and Vienna $\left(16.57^{\circ} \mathrm{E}, 48.11^{\circ} \mathrm{N}\right)$. MOZAIC raw data ( $4 \mathrm{~s}$ time resolution) are averaged over $150 \mathrm{~m}$ height intervals. Further information on MOZAIC profile data can be found in Zbinden et al. (2006).

For most analyses which include MOZAIC data, all measured MOZAIC profiles available at an airport from 09:00 UTC to 18:00 UTC are averaged for each day of the period 16 July-31 August ( $>2$ profiles per day in the case of Frankfurt). This way, the same weight is given to all days with MOZAIC measurements independently of the number of profiles on each day. The use of only daytime data allows us to analyse the times of the day with strongest photochemical activity and possibly lowest relative contribution of deposition processes. Hourly model output is interpolated to the time of the independent measured profiles and to the location of the corresponding airports. Similarly to the MOZAIC measurements, all daytime interpolated modelled profiles are averaged for each day.

\subsubsection{Measurements from EMEP and GAW}

Surface ozone measurements used for model evaluation in GEMS-GRG have been provided by the European Monitoring and Evaluation Programme (EMEP) and the Global Atmosphere Watch (GAW) databases. EMEP observations are available at http://www.emep.int/ and concern only rural and background sites scattered over Europe. Measurement data are available for around 131 stations of 27 different countries. All stations use the UV-absorption method to measure ozone. Information about the ozone data quality, calibration and maintenance procedures as well as statistical summaries and geographical distributions are given in Aas and Hjellbrekke (2005) and Hjellbrekke and Solberg (2005). The GAW trace gas data are accessible via the GAW Station Information System GAWSIS (http://gaw.empa.ch/gawsis/) from the World Data Centre for Greenhouse Gases (WDCGG) and the World Ozone and Ultraviolet Radiation Data Centre (WOUDC). Quality is controlled and local influences are eliminated by the individual station operators in order to generate regionally representative data suitable for validation of global models. Data from about $30 \mathrm{GAW}$ stations have been initially used; however, when regional average biases are calculated, steep mountain sites are disregarded due to the difficulty in assigning them to specific model levels. Detailed 
information about the GAW programme is available at http: //www.wmo.int/pages/prog/arep/gaw/gaw_home_en.html.

\subsection{Statistics used for model evaluation}

In evaluating and comparing forecast errors of chemical species it is desirable to use normalised quantities due to the differing ranges of typical concentrations of the species. We have calculated the following statistical scores recommended by Agnew et al. (2007) to summarise the degree of correspondence between forecast (f) and observations (o):

1. The bias indicates the extent to which the model underor overpredicts a set of observations. The formulation of the modified normalised mean bias $\left(B_{n}^{\prime}\right)$

$B_{n}^{\prime}=\frac{2}{N} \sum_{i}\left(\frac{f_{i}-o_{i}}{f_{i}+o_{i}}\right) \cdot 100 \%$

is used here because $B_{n}^{\prime}$ gives a measure of the forecast bias which performs symmetrically with respect to under- and overprediction. $B_{n}^{\prime}$ is bounded by the values $-200 \%$ and $+200 \%$. As an example if all modelled values lie within a factor of 2 of the corresponding observations then $B_{n}^{\prime}$ will lie in between $-66.67 \%$ and $66.67 \%$.

2. The fractional gross error $\left(E_{f}\right)$ is used as an indicator of the overall forecast error, i.e. of the deviations between model and measurements:

$E_{f}=\frac{2}{N} \sum_{i}\left|\frac{f_{i}-o_{i}}{f_{i}+o_{i}}\right| \cdot 100 \%$

$E_{f}$ gives the same weight to errors of high and low magnitude, and therefore it is preferred rather than other statistics such as the root-mean-square error (RMSE). $E_{f}$ is bounded by the values 0 and $200 \%$. If all modelled values lie within a factor of 2 of the observations then $E_{f}$ will lie in between 0 and $66.67 \%$.

To assist in the interpretation of the results, Table 3 indicates some possible values of $B_{n}^{\prime}$ and $E_{f}$ assuming that all modelled values underestimate or overestimate the measurements by a given factor.

The Pearson's correlation coefficient $(R)$ is also calculated to indicate the extent to which patterns in the modelled profiles match those in the observed profiles.

\section{Meteorology during the heat wave}

Model output as well as MOZAIC measurements of temperature, relative humidity $(\mathrm{RH})$ and wind speed were analysed for different atmospheric pressure levels - 950, 850, 700, 500 and $300 \mathrm{hPa}$ - to detect the periods with the most favourable conditions for photochemical smog formation in July and August of 2003. Elevated temperatures were found from the
Table 3. Some possible values of modified normalised mean bias $B_{n}{ }^{\prime}(\%)$ and fractional gross error $E_{f}(\%)$ assuming that all modelled values $f_{i}$ and observations $o_{i}$ are related by the relationship $f_{i}=M o_{i}$.

\begin{tabular}{lll}
\hline $\mathrm{M}$ & $B_{n}^{\prime}(\%)$ & $E_{f}(\%)$ \\
\hline $1 / 2$ & -66.67 & 66.67 \\
$2 / 3$ & -40.00 & 40.00 \\
$3 / 4$ & -28.57 & 28.57 \\
$4 / 5$ & -22.22 & 22.22 \\
1 & 0 & 0 \\
$5 / 4$ & 22.22 & 22.22 \\
$4 / 3$ & 28.57 & 28.57 \\
$3 / 2$ & 40.00 & 40.00 \\
2 & 66.67 & 66.67 \\
\hline
\end{tabular}

ground up to $700 \mathrm{hPa}$ for Paris and Frankfurt, but not for Vienna, from 2 to 14 August 2003. During the same period, RH was low within the boundary layer (up to around $850 \mathrm{hPa}$ ) for the three airports, and low wind speed was observed throughout the lower- and mid-troposphere above Paris and Frankfurt. As an example of the strong meteorological anomalies found mainly in the lower troposphere, Fig. 1 shows the evolution of temperature, relative humidity and wind speed at $850 \mathrm{hPa}$ above Frankfurt from 15 July to 31 August 2003, as measured by MOZAIC and, for illustration, as used within two of the CTMs, TM5 and MOZART. The elevated temperatures favour photochemistry while the simultaneous decreases in relative humidity and wind speed reflect the dryness and stagnation over central/western Europe during that fortnight. These results are consistent with those of Trigo et al. (2005), who found strong temperature and geopotential anomalies centred over the South of England and the Northwest of France, and much weaker anomalies for the longitude of Vienna, during the first fortnight of August.

It should be emphasised that meteorological parameters are interpolated on the grids of the CTMs from 6-hourly fields (3-hourly in the case of TM5) of the IFS meteorological reanalysis. The observed differences between TM5 and MOZART are merely introduced from spatial and temporal interpolations and are not completely negligible. Overall, there is good correspondence between measured and modelled meteorological fields, with the exception of somewhat low temperatures in MOZART over Frankfurt (Fig. 1, top) but not over the other European airports (not shown). These results confirm that the main meteorological features found for MOZAIC data in summer 2003 are generally well reproduced by the ECMWF reanalysis. However the interpolation of non-collocated coarse grid cells from different models may lead to differences for some locations. Moreover, the highest temperatures during the afternoon are not completely covered for MOZART due to the 6-hourly update of 

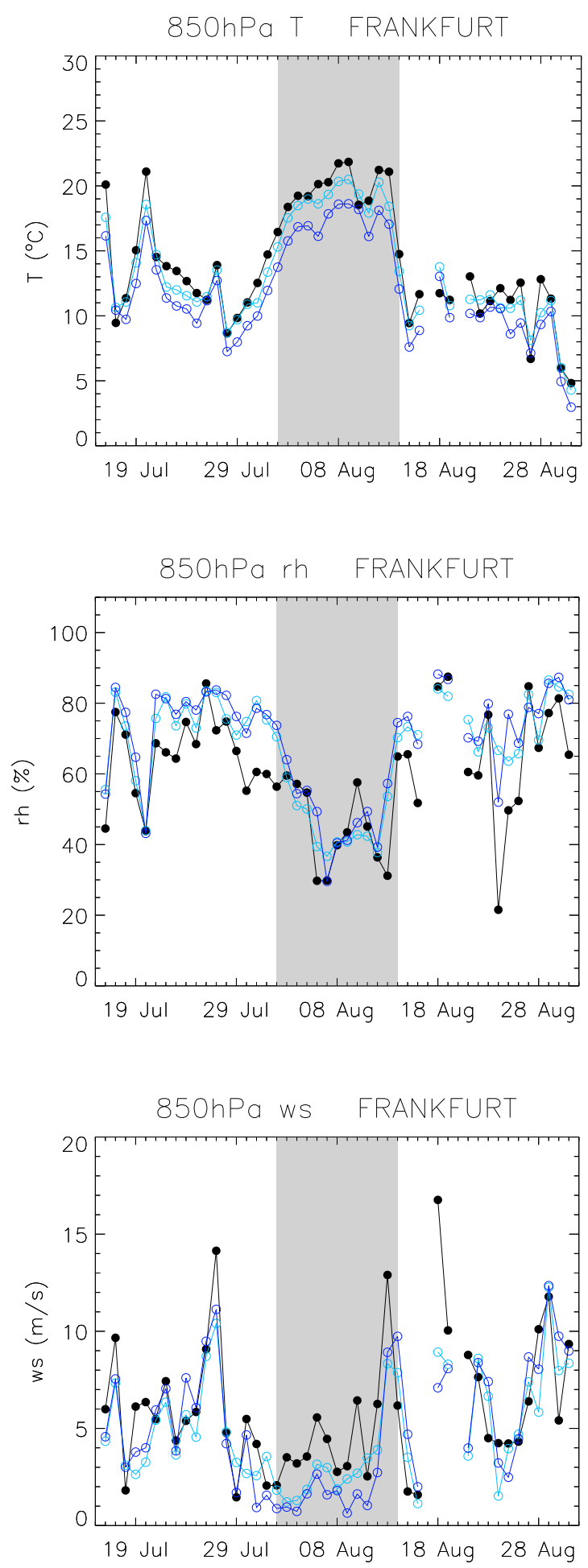

Fig. 1. Time series of daytime (09:00-18:00 UTC) average (top) temperature, (middle) relative humidity and (bottom) wind speed at $850 \mathrm{hPa}$ above Frankfurt for the period 15 July-31 August 2003. The area shaded in grey represents the heat wave period (2-14 August). Black lines represent MOZAIC measurements, dark blue is used for MOZART output and light blue for TM5-HWGL. meteorological information, which has been identified to be a main reason for the temperature bias. The impact of the frequency of the meteorological feedback used in the CTMs is addressed in Sect. 5.5.

A more detailed analysis of the meteorology during the period of analysis can be found in Tressol et al. (2008). We will analyse the same periods considered in that work - before (16-31 July 2003), during (2-14 August 2003) and after (16-31 August 2003) the heat wave - in order to test the model's performance under moderate and extreme meteorological conditions. Since Vienna lies to the east of the area with strongest anomalies, our analyses will be mainly focused on the evolution of gas pollutants above Frankfurt (airport with the best MOZAIC data coverage) and to less extent above Paris and Vienna.

\section{Air pollution during the heat wave: results from of- fline and coupled simulations}

\subsection{Analysis of surface $\mathrm{O}_{3}$ and $\mathrm{CO}$ fields}

Monthly averages of modelled fields and surface observations, including both daytime and nighttime data, will be shown in this work to illustrate the overall models' behaviour. For those analyses at the sub-monthly scale, only daytime data (09:00-18:00 UTC) will be used in order to only cover the times of the day with strong photochemical activity that have also been analysed for the MOZAIC measurements (see Section 2.2.1).

A first comparison of modelled ozone from the reference MOZART, TM5 and MOCAGE stand-alone simulations with GAW/EMEP surface measurements reflects that the global models have some difficulties in reproducing the elevated ozone mixing ratios during July and August 2003, particularly over central Europe in August (Fig. 2). Surface ozone fields are similar for MOZART and TM5, although ozone in MOZART is somewhat lower over the northern part of the European domain as well as over the Mediterranean. On the other hand, $\mathrm{O}_{3}$ from TM5 is lower over Western/Central Europe. The most remarkable feature of the surface ozone field in MOCAGE is the high mixing ratios over the Mediterranean and the Black Sea, generally in good agreement with the few measurements available over those areas. Unlike MOZART and TM5, ozone from MOCAGE is also higher over large fractions of the Atlantic Ocean and North Sea than over many continental areas. The reasons for the high $\mathrm{O}_{3}$ found over sea in MOCAGE will be investigated in Sect. 5.4.

A more detailed picture of the evolution of modelled surface $\mathrm{O}_{3}$ and $\mathrm{CO}$ fields at daytime for the three sub-periods analysed is shown for MOZART in Fig. 3. The high temperatures and stagnation of air masses during the heat wave period resulted in enhanced surface $\mathrm{O}_{3}$ mixing ratios over Western/Central Europe. This is also found for TM5 and 
Table 4. Values of modified normalised mean bias $B_{n}{ }^{\prime}(\%)$ of near-surface ozone over the European domain for 3 stand-alone and 2 coupled runs. From the GAW and EMEP surface observations plotted in Fig. 2, only EMEP measurements which are not performed at steep mountain sites (63 stations in total) have been used to calculate these biases. The five periods shown here are July and August 2003 (both daytime and nighttime data, as in Fig. 2) as well as only daytime data (as in Fig. 3) before the heat wave (16-31 July), during the heat wave (2-14 August) and after the heat wave (16-31 August).

\begin{tabular}{llllll}
\hline Model run & July & August & Before HW & During HW & After HW \\
\hline MOZART & -1.8 & -10.9 & -5.7 & -19.7 & -17.9 \\
TM5-HWGL & -0.7 & -7.0 & -2.7 & -13.9 & -4.7 \\
MOCAGE & 9.8 & -5.0 & 4.0 & -13.4 & -2.7 \\
COUPL & -16.2 & -24.8 & -1.8 & -13.0 & -11.8 \\
COUPL-ASSIM & -16.2 & -23.9 & -2.3 & -12.4 & -10.6 \\
\hline
\end{tabular}

Table 5. As Table 4 but for fractional gross error $E_{f}(\%)$.

\begin{tabular}{llllll}
\hline Model run & Jul & Aug & Before HW & During HW & After HW \\
\hline MOZART & 22.6 & 27.1 & 19.8 & 28.1 & 27.4 \\
TM5-HWGL & 21.5 & 23.2 & 18.6 & 21.5 & 18.3 \\
MOCAGE & 29.1 & 29.1 & 24.4 & 26.8 & 23.2 \\
COUPL & 26.7 & 32.8 & 20.6 & 23.8 & 23.0 \\
COUPL-ASSIM & 26.7 & 32.2 & 20.9 & 23.6 & 22.5 \\
\hline
\end{tabular}

MOCAGE (not shown). The stagnation of air masses also led to high levels of some primary pollutants in the boundary layer, as seen in the MOZART surface $\mathrm{CO}$ mixing ratios. The strongest $\mathrm{CO}$ sources during the heat wave are found over areas affected by forest fires (e.g. Portugal and Italy) and densely populated areas (e.g. England and The Netherlands).

Finally, Tables 4 and 5 present a short summary of the biases and errors in surface ozone for the MOZART, TM5 and MOCAGE stand-alone simulations as well as for the two coupled runs over the areas and periods represented in Fig. 2 and 3. Surface ozone is more underestimated by the models in August than in July, predominantly during the heat wave period. Biases are not particularly large because of the compensation of negative and positive values for different stations, as is reflected by the larger absolute values of the fractional gross error. MOCAGE overestimates ozone in July and it has smaller negative biases than the other two models in August, but fractional gross errors for this model are among the largest ones for all periods. Overall TM5 is the model that best reproduces surface ozone levels for summer 2003. Although the two IFS-MOZART coupled runs perform somewhat better than MOZART at daytime, they lead to larger errors when all data are considered. Overall, larger biases have been found for the coupled runs at nighttime compared to daytime, which might be related to problems of the coupled system to simulate the vertical mixing close to surface at night. The reason for the very similar sim- ulation of ozone in the two coupled runs, without and with assimilation, will be explained in Sect. 4.2.

\subsection{Comparison with $\mathrm{O}_{3}$ and $\mathrm{CO}$ profiles from MOZAIC}

Time series of MOZAIC measurements and stand-alone CTM simulation results at $850 \mathrm{hPa}$ illustrate that the highest ozone and $\mathrm{CO}$ mixing ratios in the lower troposphere over Frankfurt and Paris are found during the heat wave period (Fig. 4). CO is not shown for Paris, because of the low coverage of MOZAIC measurements at that airport during the period of analysis. The figure also shows the underestimation in $\mathrm{O}_{3}$ and $\mathrm{CO}$ for four of the CTM stand-alone runs (MOZART, MOZART t106, TM5-HWGL and TM5HWHR) compared to MOZAIC measurements. MOCAGE also underestimates $\mathrm{CO}$ but very clearly overestimates ozone for most days. Models capture very well the evolution of $\mathrm{O}_{3}$, which is mainly synoptically driven, but not the measured $\mathrm{O}_{3}$ levels during the heat wave. The coarse resolution TM5 (light blue) and MOZART (dark blue) runs perform similarly for $\mathrm{O}_{3}$, with somewhat lower biases for TM5 particularly over Frankfurt at the end of the heat wave period. Nevertheless TM5 clearly has problems for reproducing the measured $\mathrm{CO}$ levels, while $\mathrm{CO}$ from MOCAGE is somewhere in between TM5 and MOZART. The decrease in both $\mathrm{O}_{3}$ and $\mathrm{CO}$ above Frankfurt in the middle of the heat wave as a consequence of the ventilation by a low-pressure system is reproduced by the models. However all model runs 

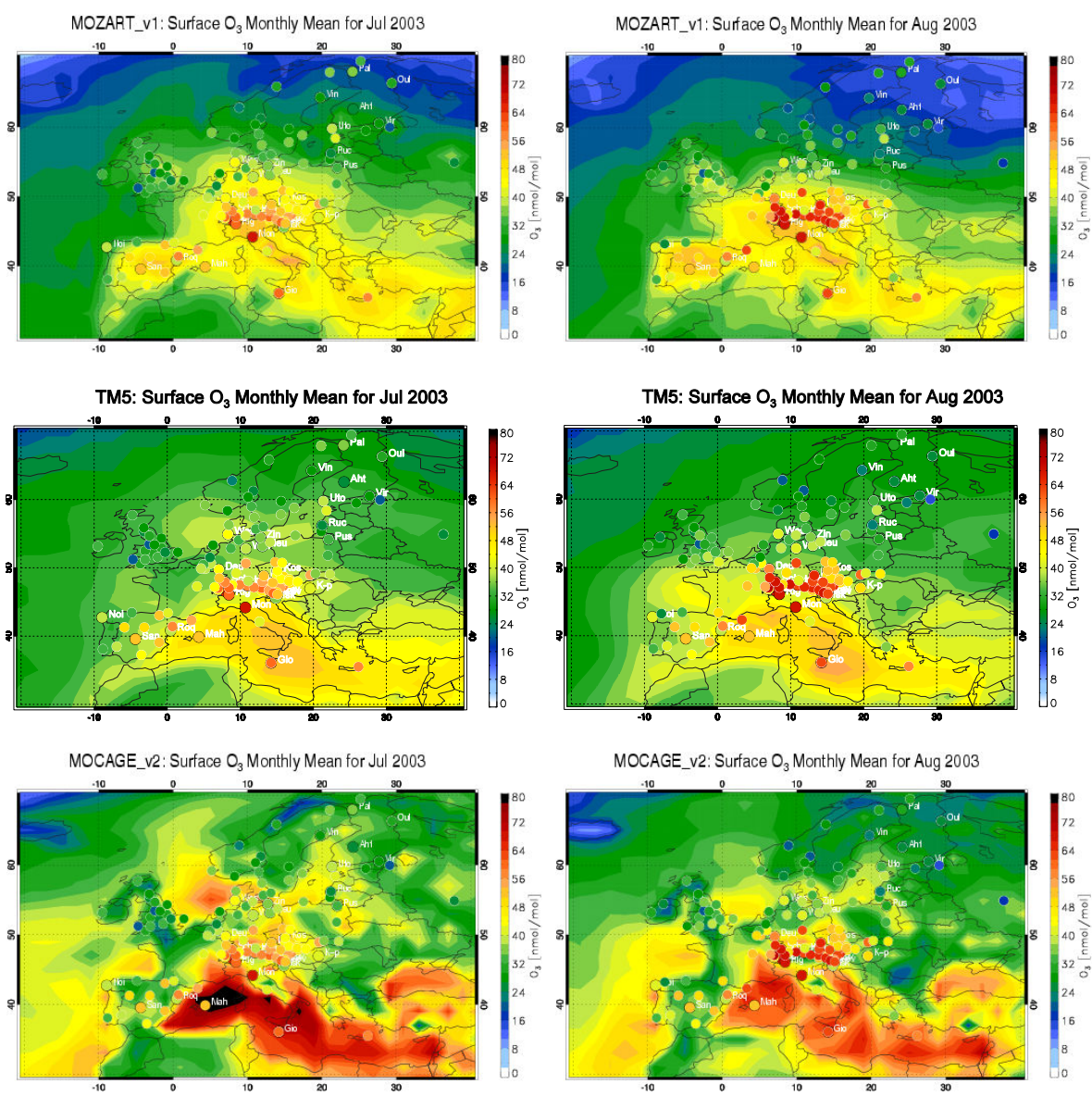

Fig. 2. Monthly average surface ozone mixing ratios (ppb) in (left) July and (right) August 2003 modelled by (top) MOZART, (middle) TM5-HWGL and (bottom) MOCAGE. Measurements from the GAW and EMEP networks are overplotted with the same colour scale. Both daytime and nighttime data are considered.

have difficulties in reproducing the previous strong increase in $\mathrm{CO}$, which is at least partly associated with the transport from Portuguese fires (Hodzic et al., 2007; Tressol et al., 2008). This was expected since the models use monthly averaged emission data and do not include a parameterisation for injection heights of fire emissions; therefore they cannot account for the strong transport of $\mathrm{CO}$ from Portuguese fires to other countries of Western and Central Europe, particularly during 6-10 August, the period for which Tressol et al. (2008) found a contribution of biomass burning to CO above Frankfurt of around 35\%. At that airport, there is a significant improvement in $\mathrm{O}_{3}$ and $\mathrm{CO}$ modelled by MOZART t106 with respect to the coarse resolution MOZART run, while no apparent improvement is usually found for TM5 with the increased resolution. Although TM5-HWHR zooms to higher resolution (compared to TM5-HWGL) over a limited area covering Europe, the TM5 model running on global $3^{\circ} \times 2^{\circ}$ already includes some features on higher resolution. As an example surface processes (emissions and depositions) are evaluated on a global $1^{\circ} \times 1^{\circ}$ resolution first, and then coarsened to global $3^{\circ} \times 2^{\circ}$. As a consequence, the difference with and without zooming is generally small.

A detailed evaluation of $\mathrm{O}_{3}$ and $\mathrm{CO}$ profiles above Frankfurt can be derived from Figs. 5 and 6. Figure 5 shows the average vertical profiles of $\mathrm{O}_{3}$ and $\mathrm{CO}$ measured by MOZAIC and simulated by various model runs during the heat wave period. Figure 6 illustrates the modified normalised mean biases over 3 atmospheric layers chosen to represent the planetary boundary layer (PBL, $p>850 \mathrm{hPa}$ ), free troposphere $(850-650 \mathrm{hPa})$ and mid-troposphere $(650-$ $300 \mathrm{hPa}$ ), for the 3 periods of analysis: before, during and after the heat wave. Results from the main MOZART3 (MOZART, MOZART t106), TM5 (TM5-HWGL, TM5HWHR) and MOCAGE stand-alone simulations as well as from the coupled IFS/MOZART runs (COUPL and COUPLASSIM) are shown.

Most model simulations underestimate $\mathrm{O}_{3}$ throughout the troposphere during the heat wave, except MOCAGE. The reasons for the ozone overestimation in this model will be separately discussed in Sect. 5.4. Despite the noticeable 

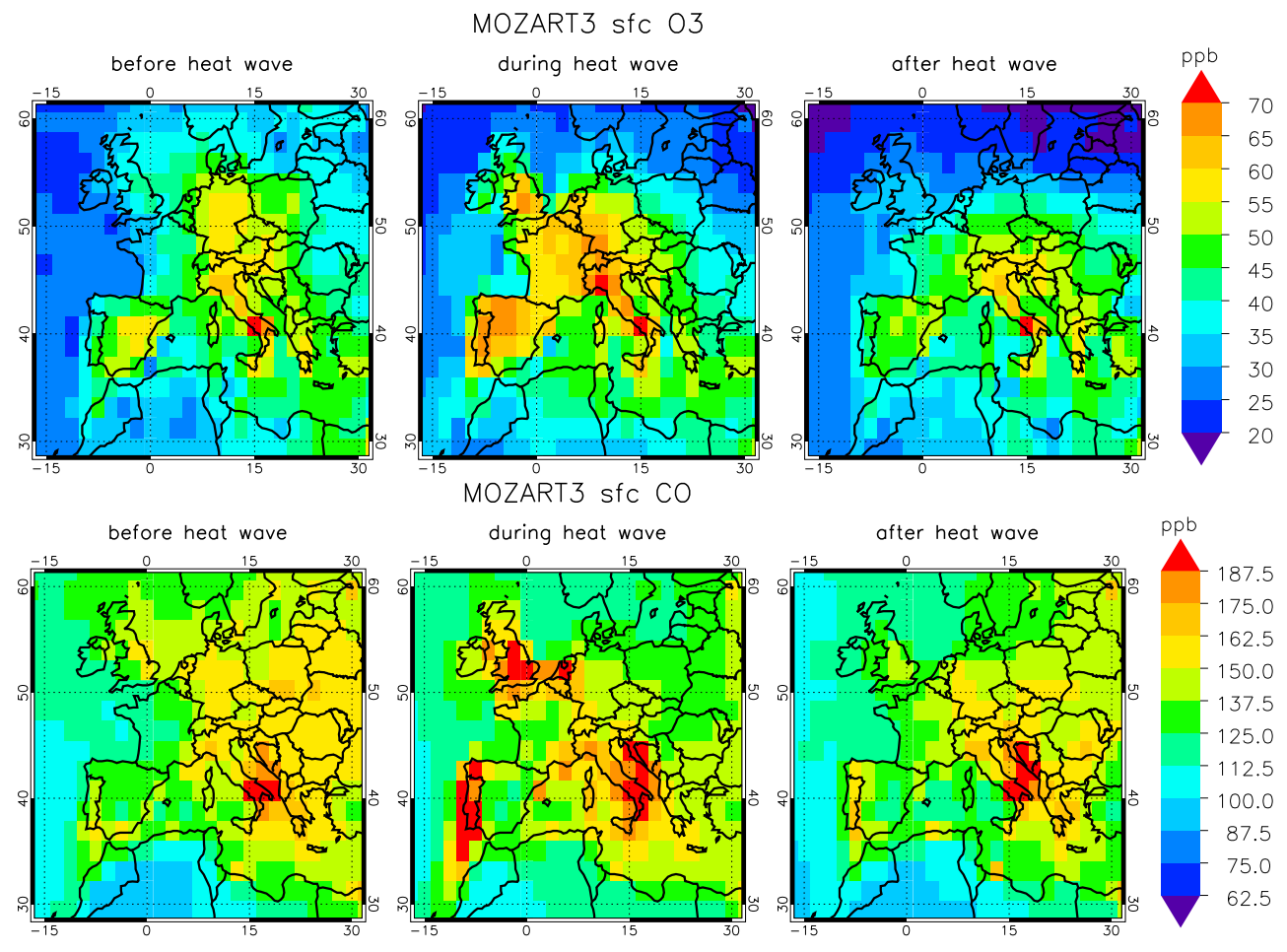

Fig. 3. Evolution of average surface (top) $\mathrm{O}_{3}$ and (bottom) CO simulated by MOZART at daytime (09:00-18:00 UTC) for the 3 periods of analysis: before (16-31 July), during (2-14 August) and after (16-31 August) the heat wave.

differences among some simulations, in most cases modelled and measured $\mathrm{O}_{3}$ lie close to each other within their range of uncertainty throughout most of the tropospheric profile (Fig. 5, left). Similar negative biases are found for the models (except for MOCAGE which has positive biases of equivalent magnitude) in the mid- and free troposphere during the three periods (Fig. 6, left) although the two coupled runs perform somewhat worse than the CTM stand-alone runs. A different picture is found for $p>850 \mathrm{hPa}$, where the strongest model underestimation takes place during the heat wave period while biases are small and positive (except for TM5 before the heat wave) in the other two periods. One of the most remarkable features is the improvement in modelled $\mathrm{O}_{3}$ for the lowest levels during the heat wave in MOZART t106 $\left(B_{n}^{\prime} \approx-20 \%\right)$ with respect to the coarser MOZART run $\left(B_{n}^{\prime} \approx-35 \%\right)$. In addition, the shape of the vertical profile achieved with the higher resolution reproduces the characteristic ozone maximum at about $800 \mathrm{~m}$ altitude and leads to a much better correlation in MOZART t106 $(r=0.82)$ compared to MOZART $(r=0.23)$ during the heat wave period. It is also noteworthy the lack of improvement in the modelling of $\mathrm{O}_{3}$ with the coupling (compare COUPL in violet with MOZART in dark blue), with the exception of the lowest levels during the heat wave. These results show that the one-hour coupling of a CTM such as MOZART with IFS meteorological fields (COUPL run) does not necessary improve the tropospheric ozone modelling for this case study. The differences between the two coupled runs without (COUPL) and with (COUPL-ASSIM) data assimilation are small for all periods, probably because of the reduced sensitivity of satellite UV measurements to $\mathrm{O}_{3}$ absorption within the troposphere. The possibility of retrieving tropospheric ozone from measurements in the infrared spectral range is relatively recent and has started to be explored thanks to instruments such as the Tropospheric Emission Spectrometer (TES) (e.g. Beer et al., 2001; Bowman et al., 2002) and the Infrared Atmospheric Sounding Interferometer (IASI) (e.g. Turquety et al., 2004; Eremenko et al., 2008). This should bring major improvements to the assimilation of tropospheric ozone in the future.

All model simulations underestimate $\mathrm{CO}$ in the troposphere, particularly in the free and lower troposphere, during the heat wave period (Figs. 5 and 6, right). Although TM5 reproduces the shape of the measured profile $(r=0.98$ for TM5-HWGL compared to 0.93 and 0.94 for MOCAGE and MOZART, respectively), the largest biases are found for this model everywhere in the tropospheric profile. TM5 bias is up to nearly $-80 \%$ in the PBL, which corresponds to an underestimation of the measurements by more than a factor of two (see Table 3). This is partly caused by missing biogenic $\mathrm{CO}$ emissions in these TM5 simulations, which account for about $15 \%$ of the total CO emissions, as well as 

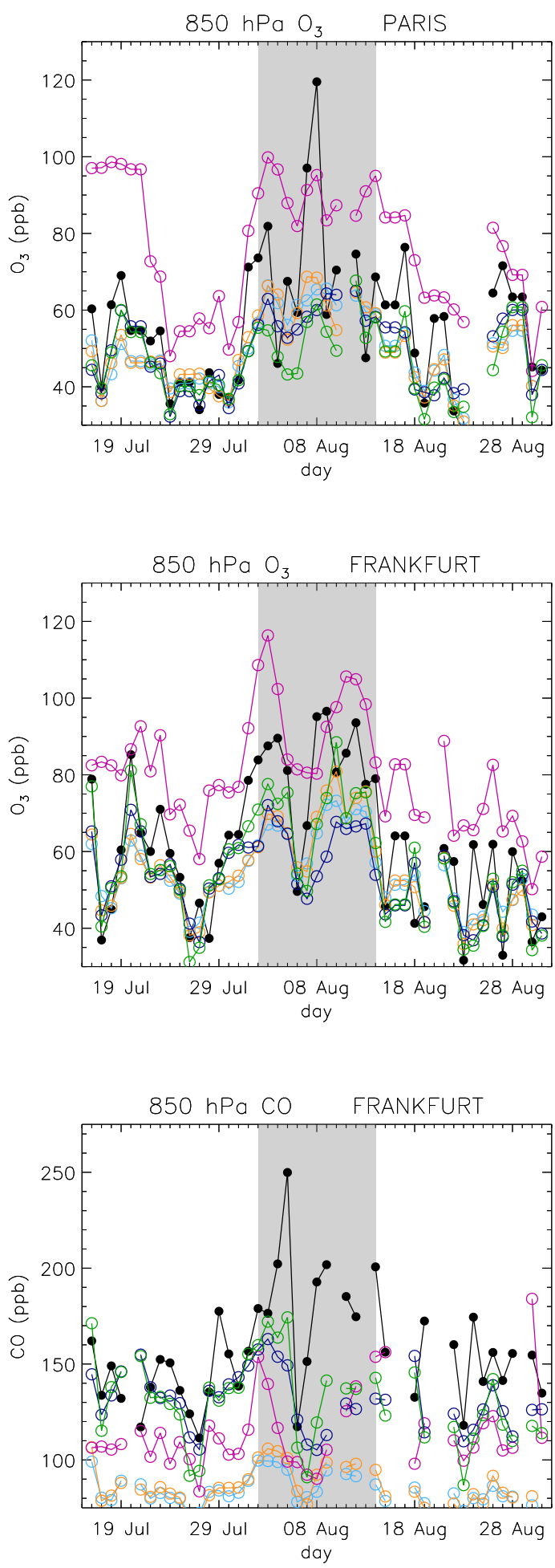

Fig. 4. Time series of daytime average (top) $\mathrm{O}_{3}$ above Paris as well as (middle) $\mathrm{O}_{3}$ and (bottom) $\mathrm{CO}$ above Frankfurt at $850 \mathrm{hPa}$ for the period 15 July-31 August 2003. The area shaded in grey represents the heat wave period (2-14 August). Black lines represent MOZAIC measurements, light blue is used for TM5-HWGL output, orange for TM5-HWHR, dark blue for MOZART, green for MOZART t106 and magenta for MOCAGE. by the under-representation of atmospheric oxidation to $\mathrm{CO}$ as a consequence of a somewhat low global mean methane surface concentration of $1760 \mathrm{ppb}$ (estimated contribution to $\mathrm{CO}$ of about $10 \mathrm{ppb}$ ) and by some missing higher hydrocarbons (about $10 \%$ of the total $\mathrm{CO}$ ). In addition, the underrepresentation of methane and VOC oxidation results in $\mathrm{OH}$ increases and further $\mathrm{CO}$ reduction by oxidation with $\mathrm{OH}$. The combination of these effects is responsible for a negative bias in the $\mathrm{CO}$ background concentrations in the Northern Hemisphere. The zoom to $1^{\circ} \times 1^{\circ}$ (TM5-HWHR) leads only to a small improvement. MOZART has more problems to reproduce $\mathrm{CO}$ levels in the lower troposphere than for the rest of the profile, particularly during the heat wave period when for those low altitudes the negative bias is below $-40 \%$. Although CO fields from MOZART and MOCAGE do not differ significantly from each other over some atmospheric layers and periods, the underestimation of $\mathrm{CO}$ by MOCAGE is larger for the lower troposphere before the heat wave and in the boundary layer during the heat wave. This might be partly related to enhanced $\mathrm{CO}$ oxidation in MOCAGE since this model contains around twice as much $\mathrm{OH}$ as MOZART in the proximity of the PBL. Similarly to what was found for $\mathrm{O}_{3}$, the MOZART simulation with improved resolution (MOZART t106) clearly reduces the negative biases during the heat wave, but only in the lower troposphere. Lower biases are also found for the coupled IFS/MOZART (COUPL, violet) simulation compared to the base MOZART stand-alone run (dark blue). Since the chemistry in the coupled system is the same as in the MOZART runs, the improved results are most probably due to the improved meteorology and transport (fully modelled meteorology in the coupled model compared to 6-h meteorological feedback in MOZART). In addition, the assimilation of CO columns from MOPITT (COUPL-ASSIM, red) further improves the comparisons with MOZAIC data, reducing negative biases to less than $20 \%$ for all tropospheric levels and periods with the exception of the lower troposphere during the heat wave.

Biases were also calculated for vertical profiles above Paris (Fig. 7) and Vienna (Fig. 8). No results are shown for $\mathrm{CO}$ above Paris because of low data availability. In the case of ozone, the biases within the mid- and free troposphere above Paris and Vienna are very similar to those found above Frankfurt. However some differences can be seen in the PBL, where the sign of the biases seems to change from the west to the east of Europe. Above Paris, located to the west of Frankfurt, there are positive biases for all models outside the heat wave period, and even for the MOZART high resolution run (MOZART t106) and again for MOCAGE during the heat wave, while the negative biases for the other models during the heat wave are small. Ozone above Paris is likely to be more affected by titration with NO than above Frankfurt due to larger emissions from Paris. It is possible that such effects, which constitute an important ozone sink, are not well represented in the coarse grid cells of the global models, leading 

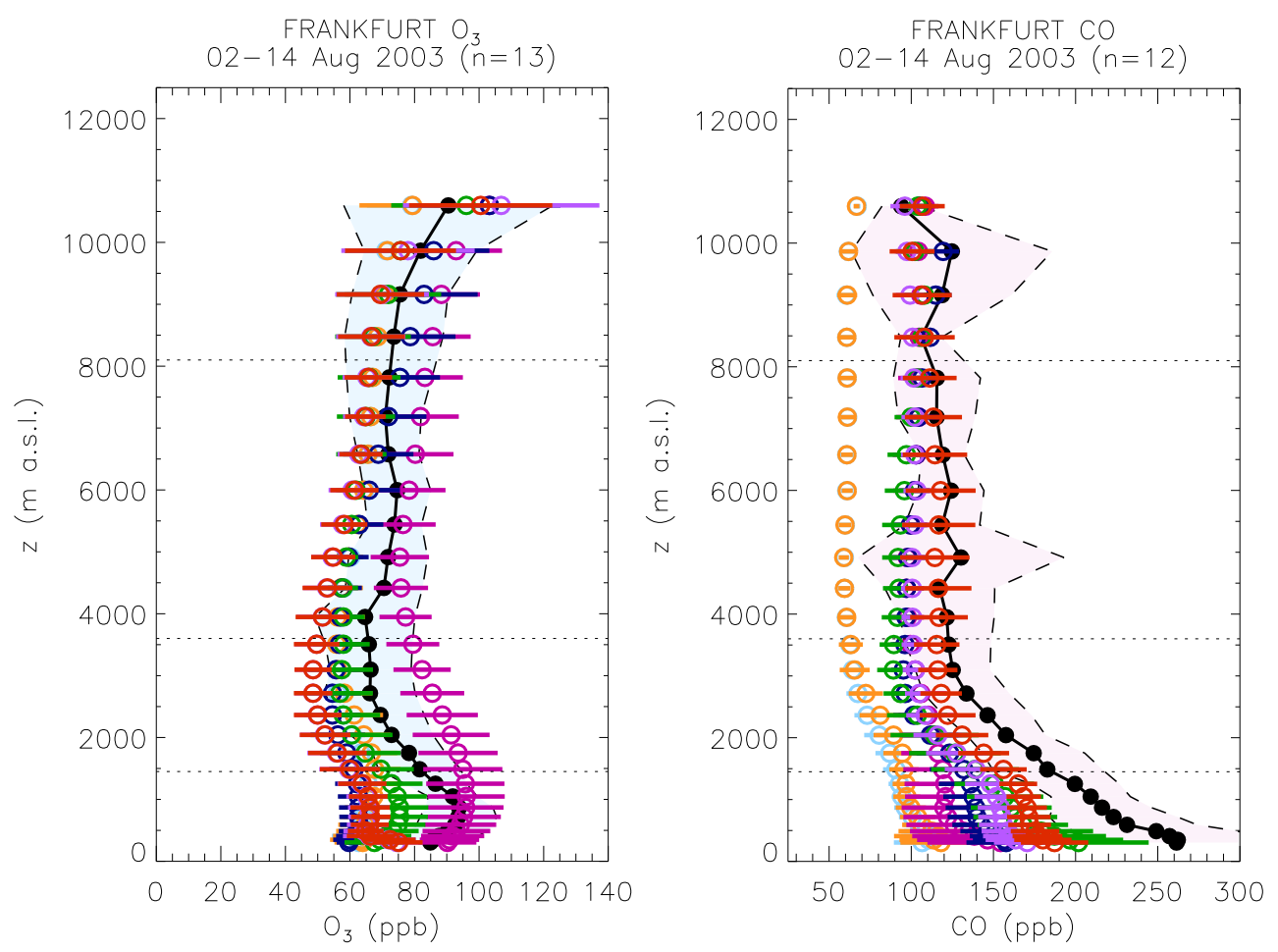

Fig. 5. Average (circles) and standard deviations (shaded area in the case of MOZAIC measurements and horizontal bars for models) of (left) $\mathrm{O}_{3}$ and (right) $\mathrm{CO}$ mixing ratios above Frankfurt during the heat wave period. MOZAIC measurements in black, TM5-HWGL in light blue, TM5-HWHR in orange, MOZART in dark blue, MOZART t106 in green, MOCAGE in magenta, COUPL in violet and COUPL-ASSIM in red. Only daytime data (09:00-18:00 UTC) have been considered. The number of days with data used is indicated on the top of the plots. The horizontal dashed lines represent, from bottom to top, the 850, 650 and $300 \mathrm{hPa}$ pressure levels.

to a compensation of the negative biases in ozone caused by other modelled processes around Paris. Above Vienna, to the east of Frankfurt, there are no important differences with respect to Frankfurt during the heat wave period but biases are more negative (less positive for MOCAGE) after the heat wave. In the case of $\mathrm{CO}$ above Vienna, there is a significant reduction in the negative bias within the PBL for most models and periods compared to Frankfurt. This might be partly due to the fact that Vienna is outside the area of strong re-circulation of European emissions and also farther from some biomass emission sources such as Portugal fires.

To summarise, the strongest negative biases in modelled $\mathrm{O}_{3}$ and $\mathrm{CO}$ are found for the PBL during the heat wave period, with the exception of an overestimation of ozone by MOCAGE throughout most of the troposphere. TM5 cannot reproduce the measured $\mathrm{CO}$ mixing ratios in any of the three periods of analysis. The increased horizontal resolution (MOZART t106) leads to improvements in the PBL particularly during the heat wave. The coupled system lowers the $\mathrm{CO}$ biases in the free troposphere and PBL during the heat wave, and the assimilation successfully reduces those biases for all layers during and after the heat wave. However the somewhat different results found for Frankfurt, Paris and Vienna suggest that the geographical location of the airports with respect to the main area affected by the heat wave as well as local effects in the proximity of the airports can be significant.

\section{Sensitivity of CTMs to a number of factors}

Two CTM simulations with improved horizontal resolution have been compared to MOZAIC measurements in Sect. 4 . Additional results from the sensitivity of MOZART to horizontal resolution will be shown here. In addition, further sensitivity runs on emissions as well as on the influence of soil wetness on the dry deposition of ozone were performed with TM5 (see summary in Sect. 2.1.1 and Table 2). Results from these sensitivity runs will be presented in this section to shed more light on some of the important processes that might be underrepresented in the models. The reasons for the ozone overestimation in MOCAGE will also be examined here based on the VOC chemistry and dry deposition velocities in this model. Finally, results from a MOZART forecast run with 1-h meteorological input will be shown to evaluate the impact of the frequency of the meteorological feedback used in the CTMs. 

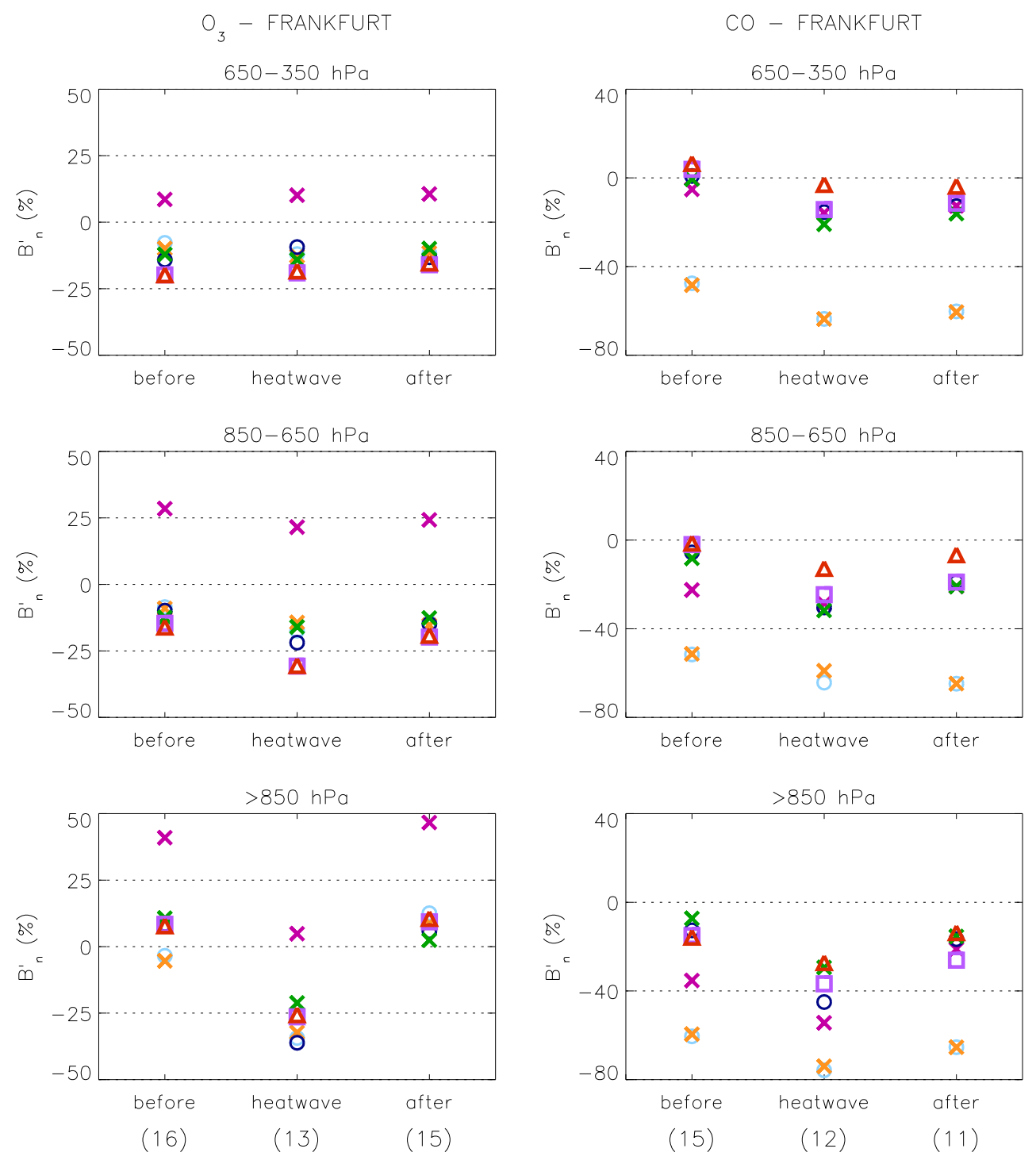

Fig. 6. Modified normalised mean biases of (left) $\mathrm{O}_{3}$ and (right) $\mathrm{CO}$ mixing ratios for three atmospheric layers above Frankfurt during the three periods of analysis. The total number of days with data for each period are shown in brackets. Only daytime data (09:00-18:00 UTC) have been considered. TM5-HWGL in light blue, TM5-HWR in orange, MOZART in dark blue, MOZART t106 in green, MOCAGE in magenta, COUPL in violet and COUPL-ASSIM in red.

\subsection{Horizontal resolution}

Figure 9 illustrates the differences between the MOZART run with increased horizontal resolution (MOZART t106) and the reference MOZART-3 stand-alone run (MOZART) for some relevant species in the lowest tropospheric levels during August 2003. The species shown here are two primary pollutants $\left(\mathrm{CO}, \mathrm{NO}_{\mathrm{x}}\right)$, a pollutant with both primary and secondary contributions ( $\mathrm{HCHO}$ ), a secondary pollutant $\left(\mathrm{O}_{3}\right)$, and a termination product (hydrogen peroxide, $\mathrm{H}_{2} \mathrm{O}_{2}$ ) which results from one of the main reactions that remove $\mathrm{HO}_{2}$ radicals from the troposphere. Note that the lowest model level is shown for the three first species, while $850 \mathrm{hPa}$ has been preferred for $\mathrm{O}_{3}$ and $\mathrm{H}_{2} \mathrm{O}_{2}$ because of the stronger removal of these two species by deposition processes as well as by chemical loss (titration with NO) in the case of ozone close to surface. With the increase in horizontal resolution, mixing ratios of primary species $\left(\mathrm{CO}\right.$ and $\left.\mathrm{NO}_{\mathrm{x}}\right)$ at surface are enhanced over North-Eastern France, Belgium, Germany, Switzerland, parts of Italy, Austria, the Czech Republic and other areas of Eastern Europe; however CO clearly decreases over Iberia and the Mediterranean while small reductions of $\mathrm{NO}_{\mathrm{x}}$ are observed over large areas outside the core of the heat wave. $\mathrm{HCHO}$ and $\mathrm{H}_{2} \mathrm{O}_{2}$ increase over large parts of the European continent, with special intensity over Eastern France, Southern Germany, Switzerland, Northern Italy and 

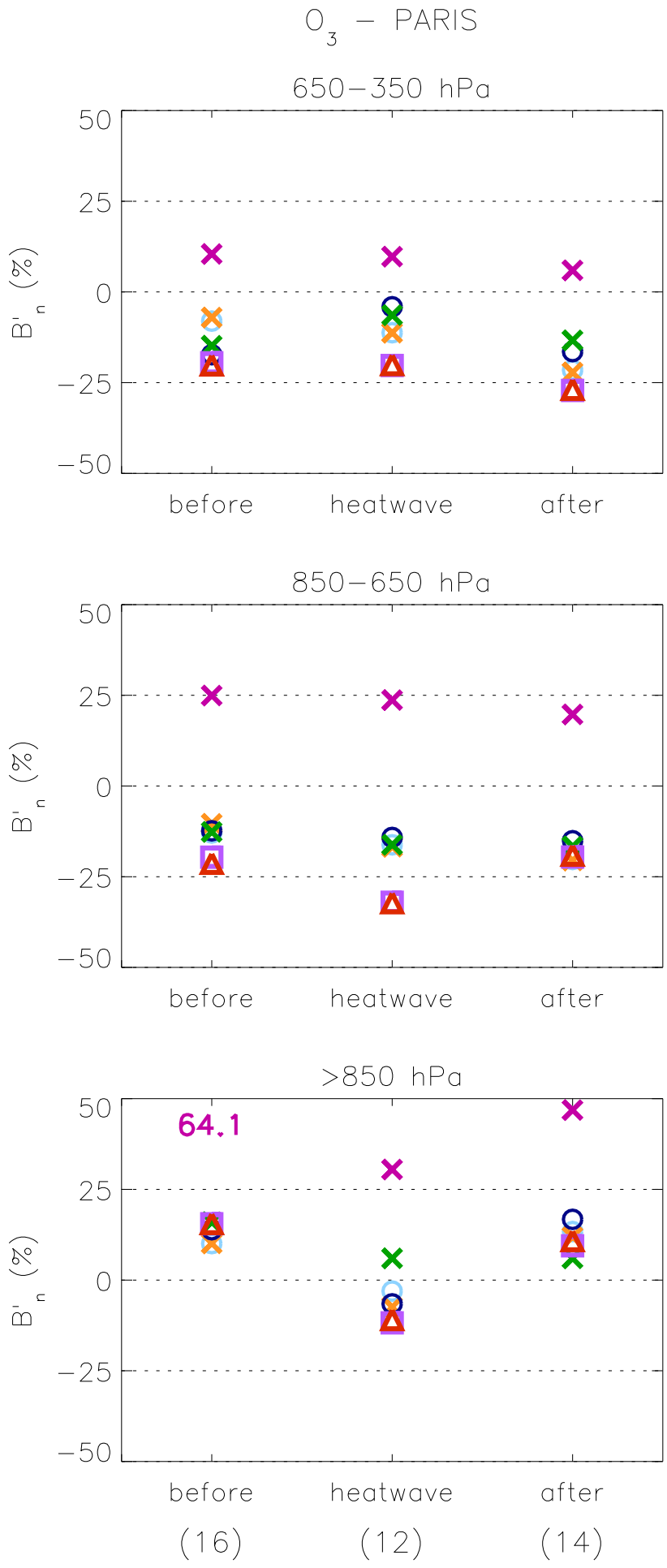

Fig. 7. As Fig. 6 but only for $\mathrm{O}_{3}$ above Paris. In the case of MOCAGE for the lowest layer before the heat wave, the numerical value of $B_{n}^{\prime}$ is explicitly indicated because it is outside the plotting area.

Austria, while they decrease over other parts of the domain such as Iberia and the Mediterranean. Finally, ozone increases over a large fraction of the domain, especially over the western/central areas of the continent which were under the influence of the heat wave (e.g. Eastern France, Benelux, Germany, Switzerland, the northern half of Italy and Austria) and decreases over other areas. These results confirm that the increase in horizontal resolution in MOZART leads to enhanced accumulation and recirculation of pollution and subsequent stronger photochemical production within the lower tropospheric levels over western/central Europe, while the effect is the opposite over other areas. In the case of ozone, it is also possible that the production/destruction regime changes over some areas as a consequence of the higher horizontal resolution.

\subsection{Emissions}

Output fields from the runs TM5-HWEE (extra 25\% anthropogenic emissions of $\mathrm{NO}_{\mathrm{x}}, \mathrm{CO}$, and NMVOC over Europe) and TM5-HWEN (no anthropogenic emissions of $\mathrm{NO}_{\mathrm{x}}, \mathrm{CO}$, and NMVOC outside Europe) were compared to those from TM5-HWHR (denominated here control run) over the European domain for the three periods of analysis. The normalised differences between the sensitivity (SENSIT) and control (CNTRL) runs provide information on the relative importance of European pollution and transboundary transport of pollution, respectively. The following formula is used to allow for a direct comparison with the calculated values of modified normalised mean bias $\left(B_{n}^{\prime}\right)$ :

NormDiff $=2 \cdot\left(\frac{\text { SENSIT }- \text { CNTRL }}{\text { SENSIT }+ \text { CNTRL }}\right) \cdot 100 \%$

Results are briefly summarised here (plots not shown):

- HWEE vs. HWHR: The response of modelled surface $\mathrm{CO}$ to the $25 \%$ increase in European anthropogenic emissions is of around 5-15\% CO increase for a large part of Western/Central Europe during the heat wave, the maximum differences being found over England, Northern France, Belgium, The Netherlands, and Western Germany. In the case of ozone, this sensitivity run results in an increase of 5-10\% throughout the PBL for the same area and period. The magnitude of this increase is small compared to the modified normalised mean biases of $\mathrm{O}_{3}$, which are more negative than $-30 \%$ for altitudes below $850 \mathrm{hPa}$ both in TM5-HWHR and MOZART (see biases for these models in orange and dark blue, respectively, in the lowest panel of Fig. 6, left). These results indicate that uncertainties in European emissions cannot completely explain the underestimation of surface ozone seen both for TM5-HWHR and MOZART. Some nitrogen containing species seem to be more sensitive to the increase in European anthropogenic emissions, with an enhancement of more 

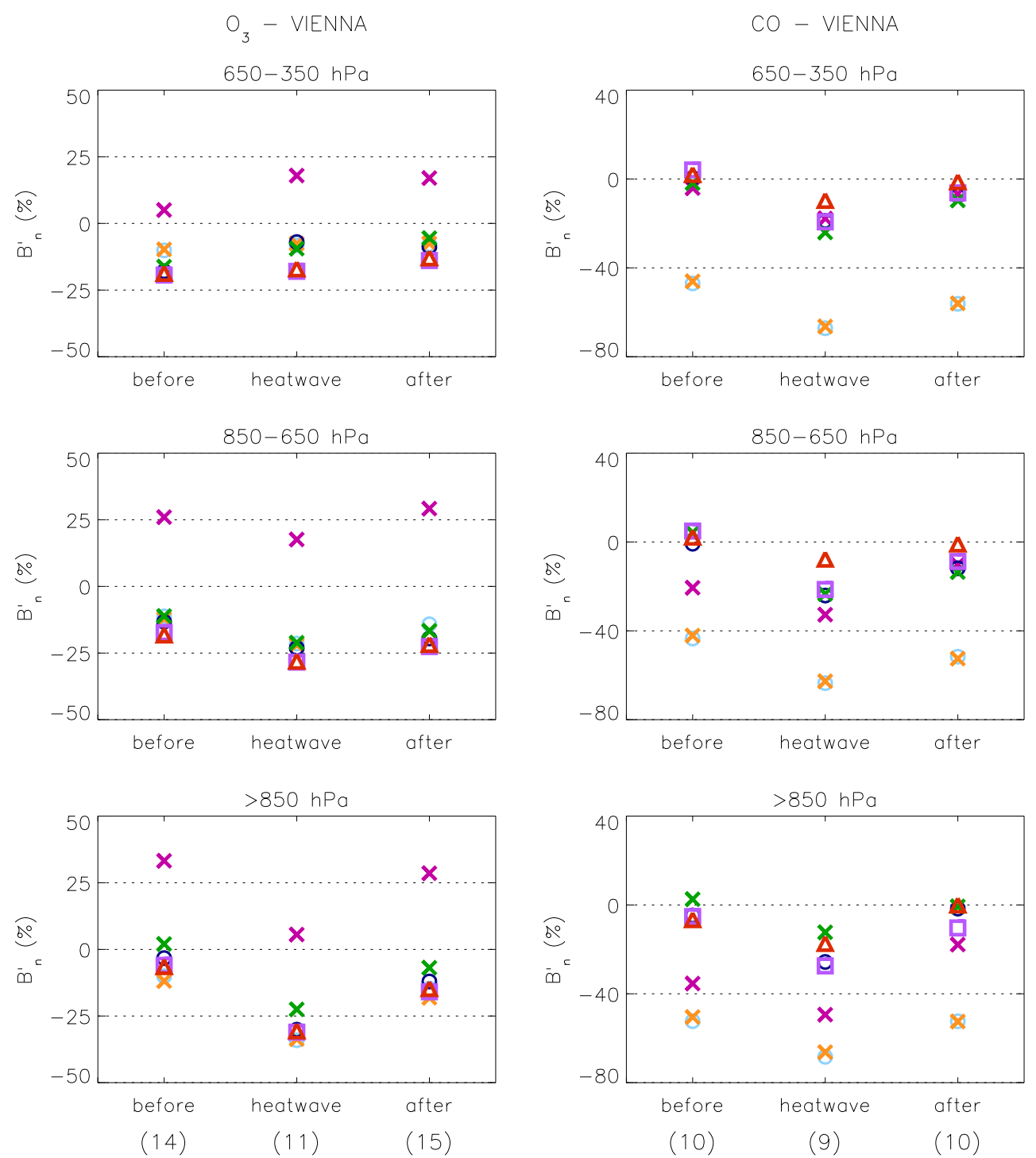

Fig. 8. As Fig. 6 but for Vienna.

than $15 \%$ found for $\mathrm{NO}_{\mathrm{x}}$ and around $20 \%$ or higher for $\mathrm{HNO}_{3}$ and PAN mixing ratios for some areas of Western/Central Europe within the boundary layer. The generally lower $\mathrm{CO}$ increases resulting from this run - compared to those of nitrogen containing species - might be partly related to the longer lifetime and higher importance of background concentrations in the case of CO.

- HWEN vs. HWHR: Surface CO decreases by no more than 5\% if anthropogenic emissions are turned off outside Europe. This influence increases with altitude up to a $10 \%$ decrease at $300 \mathrm{hPa}$. The largest influence of long-range transport on surface ozone in Europe is found for the period before the heat wave, while $\mathrm{O}_{3}$ decreases by only $0-10 \%$ over most of the continent during the heat wave period with the HWEN run. This rel-

atively small influence of transboundary transport as a consequence of the stagnation of air masses during the heat wave is consistent with the results from previous Lagrangian model simulations (Tressol et al., 2008).

The comparison of these simulations with MOZAIC measurements above Frankfurt (Fig. 10) prove that the largest influence of emissions outside Europe (HWEN compared to HWHR) is found in the mid- to upper troposphere. Within 650 to $300 \mathrm{hPa}$, around $-20 \%$ excess bias for $\mathrm{O}_{3}$ without emissions outside Europe is found while the influence on $\mathrm{CO}$ biases is smaller. The influence of non-European emissions on ozone within the PBL is particularly small during the heat wave. The largest effect of European emissions is mainly found in CO levels within the PBL for all periods (e.g. decrease of CO bias by close to $15 \%$ in the PBL during the heat 

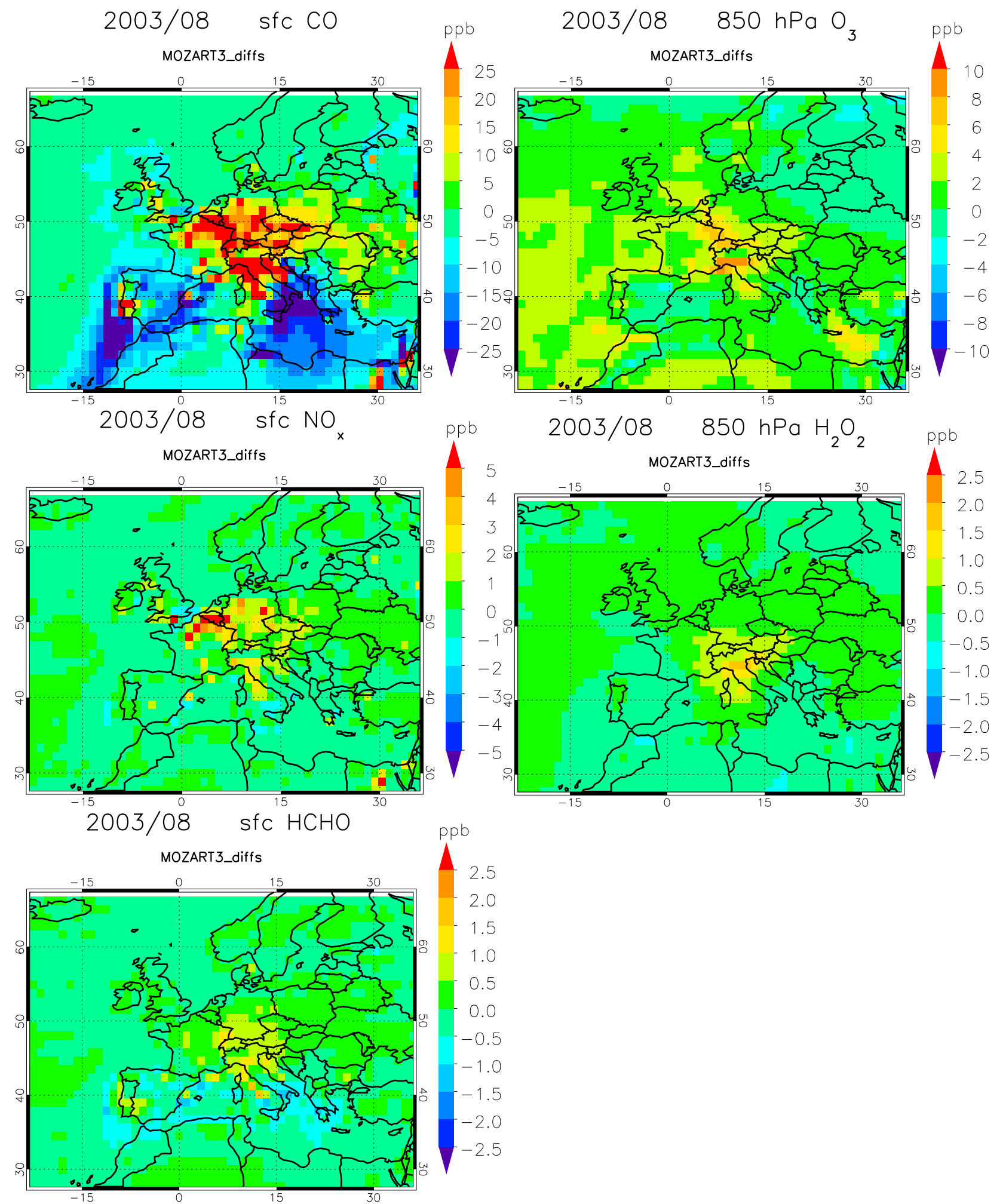

Fig. 9. Difference between MOZART-3 simulation with increased horizontal resolution (MOZART t106) and reference MOZART-3 standalone run (MOZART) for surface $\mathrm{CO}$, surface $\mathrm{NO}_{\mathrm{x}}$, surface $\mathrm{HCHO}, 850 \mathrm{hPa} \mathrm{O} 3$ and $850 \mathrm{hPa} \mathrm{H}_{2} \mathrm{O}_{2}$ in August 2008 . Both daytime and nighttime data are considered. 

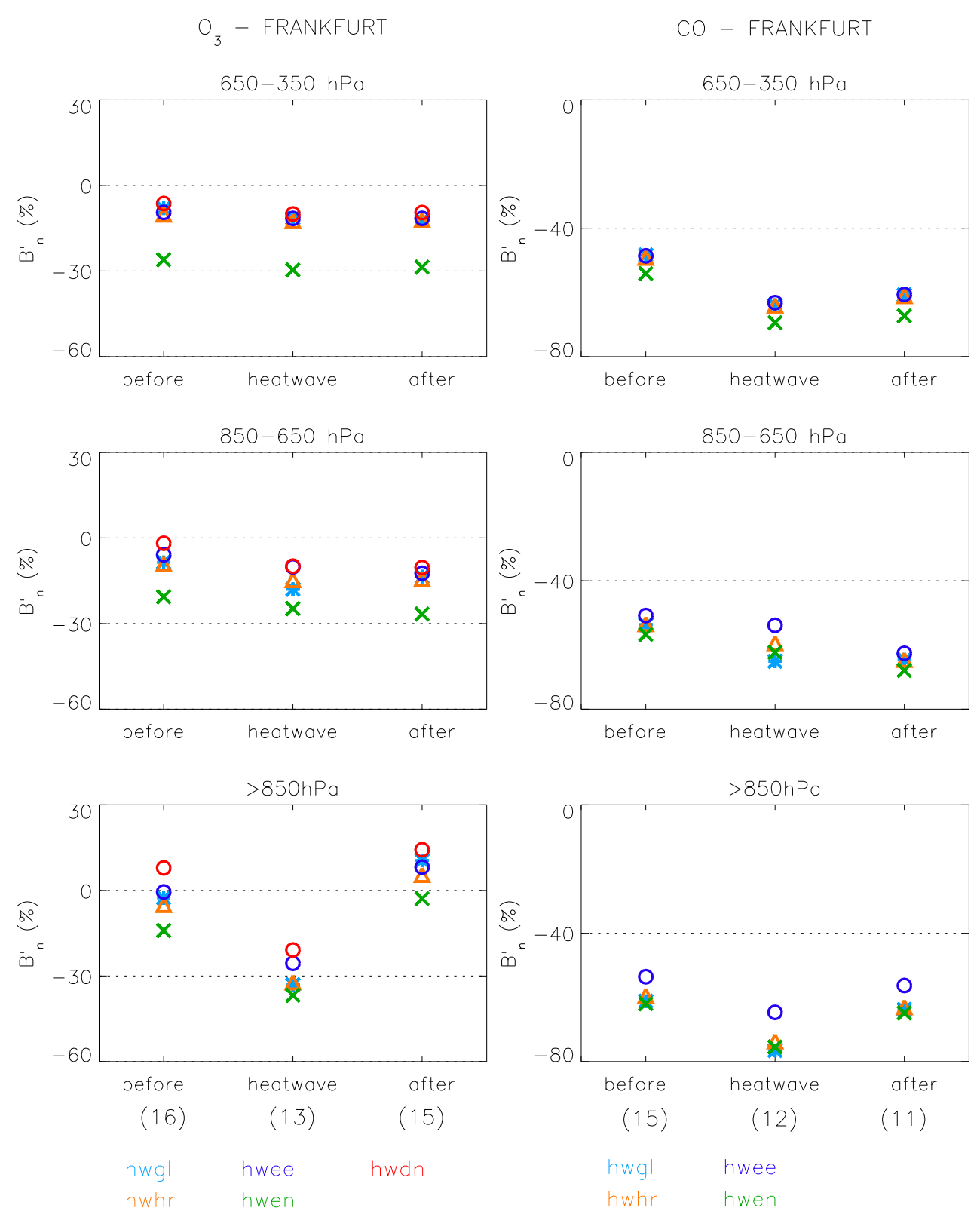

Fig. 10. Modified normalised mean biases for daytime (left) $\mathrm{O}_{3}$ and (right) $\mathrm{CO}$ mixing ratios from different TM5 runs (see summary in Table 2) for three atmospheric layers above Frankfurt during the three periods of analysis. The total numbers of days with data for each period are shown in brackets. Only daytime data (09:00-18:00 UTC) have been considered.

wave for HWEE compared to HWHR) and to lesser extent in $\mathrm{O}_{3}$ within the PBL during the heat weave. Nearly identical results were found for Paris and Vienna (not shown). These comparisons confirm that uncertainties in emissions and long-range transport cannot completely account for the underestimation of $\mathrm{CO}$ and $\mathrm{O}_{3}$ by the models within the PBL during the heat wave.

\subsection{Water stress and dry deposition of ozone}

The evolution of the dry deposition velocities of ozone over the European domain was evaluated in TM5 and compared to those from MOZART for the March-August 2003 period. Dry deposition of ozone and other species is prescribed in the MOZART version used in this analysis. As a consequence, the evolution of the dry deposition velocities for ozone follows the typical seasonal cycle for a normal year, with a moderate increase over central Europe (area of main interest for the heat wave) throughout spring until June due to 
the vegetation growth, and a slight decay from July to August. However 2003 was not a typical year and the high temperatures and dryness starting in spring and accentuated during summer caused stress to the vegetation, with subsequent stomata closure and a probably strong increase in the stomatal resistances to dry deposition. Dry deposition velocities in TM5 are more realistic because they are calculated interactively. Dry deposition velocities of ozone over central Europe are somewhat lower in TM5-HWGL $(0.5-0.7 \mathrm{~cm} / \mathrm{s}$ over Eastern France, Southern Germany and the Czech Republic) than in MOZART $(0.6-0.7 \mathrm{~cm} / \mathrm{s}$ over the same area) during June and July. In addition, the decrease in deposition velocities from July to August is much more remarkable in TM5, with around $0.2 \mathrm{~cm} / \mathrm{s}$ decrease in this model over the mentioned area and less than $0.1 \mathrm{~cm} / \mathrm{s}$ decrease in MOZART.

In TM5, dry depositions are computed based on the resistances approach (Wesely, 1989), with deposition velocity

$V_{d}=1 /\left(R_{a}+R_{b}+R_{c}\right)$

where

$R_{a}=$ aerodynamic resistance

$R_{b}=$ quasi-laminar resistance

$R_{c}=$ surface (or bulk) resistance, which can be decomposed

in stomatal $\left(R_{\text {stom }}\right)$ and non - stomatal $\left(R_{\text {nons }}\right)$ resistance

In the land surface sub-model of IFS, the soil is discretised in three layers: $0-0.07 \mathrm{~m}, 0.07-0.21 \mathrm{~m}$, and $0.21-1.00 \mathrm{~m}$. The wetness of the uppermost soil layer $(0-0.07 \mathrm{~m})$ is described by the water stress (ws), parameter which can be passed to the CTM. In TM5 the stomatal resistance is inversely proportional to the water stress ws $\left(R_{\text {stom }} \sim 1 / \mathrm{ws}\right)$. Figure 11 illustrates the evolution of the soil wetness and water stress for a grid box centred at $\left[8.5^{\circ} \mathrm{E}, 49.5^{\circ} \mathrm{N}\right]$ covering Frankfurt. The driest periods - those with soil wetness lower than $\sim 20 \%$ or water stress lower than $\sim 40 \%$ - are shown with grey background. The longest dry period over that area is 6-16 August. Comparisons with other grid cells, e.g. $\left[4.5^{\circ} \mathrm{E}, 49.5^{\circ} \mathrm{N}\right]$ over Belgium, reveal slightly longer dry periods towards the west of Europe (not shown).

Although there might be no particular reason to question the values of modelled ws for summer 2003, the choice of the soil layer might be considered. As an example it might have been more realistic to use another soil wetness field, not based on the uppermost soil layer but a deeper one corresponding to the roots of the trees, in the parameterisation of $R_{\text {stom. }}$. We performed a sensitivity run (TM5-HWDN) with water stress set to 0.1 , i.e. $10 \%$, over the European domain for the 3-month period June-August 2003. Setting ws to 0.1 for the whole period is not realistic but allows to quantify the maximum effect of this parameter and set up an upper limit of how much the uptake by stomata contributes to the ozone sinks. The effect of decreasing ws is that $R_{\text {stom }}$ becomes very
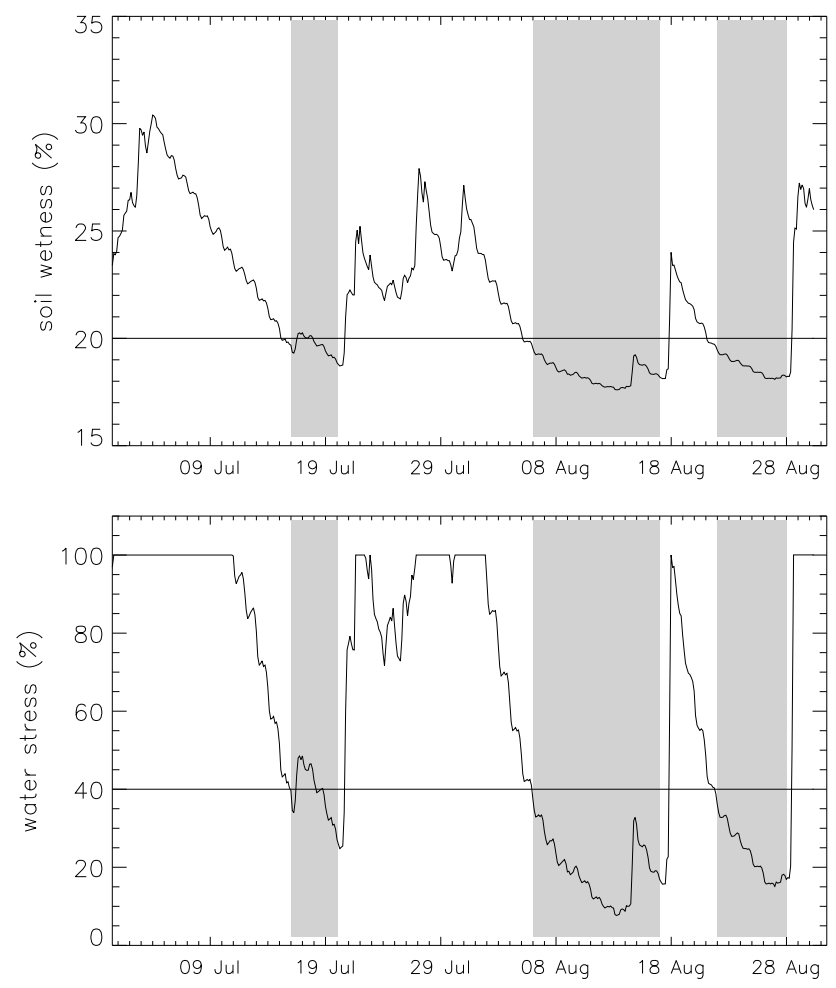

Fig. 11. Evolution of the wetness of the uppermost soil layer (0$0.07 \mathrm{~m}$ ) and the water stress for the grid cell centred at $\left[8.5^{\circ} \mathrm{E}\right.$, $49.5^{\circ} \mathrm{N}$ ] covering Frankfurt. Grey background has been used to highlight periods of drought (soil wetness lower than $\sim 20 \%$ and water stress lower than $\sim 40 \%$ ). Data source: ECMWF reanalysis for 2003.

large for a long timeframe. Under these circumstances, $R_{c}$ is larger than under normal conditions and the deposition velocity decreases, yielding higher ozone concentrations.

The absolute and percentage surface $\mathrm{O}_{3}$ increase resulting from this sensitivity run is shown in Fig. 12. Ozone increases nearly everywhere in the domain. The results of the sensitivity study look reasonable over Western/Central Europe, with absolute $\mathrm{O}_{3}$ increases of up to $20 \mathrm{ppb}$ and relative increases generally lower than $32 \%$. However the strong relative increase of even over $40 \%$ found for some areas where the ozone levels were lower than $40 \mathrm{ppb}$ in the reference run (e.g. Southern Scandinavia and a considerable fraction of Eastern Europe) does not seem to be realistic. We have shown that the soil wetness has a discernible impact on ozone concentrations; however, by increasing the stomatal resistance over the whole domain the model deteriorates for some areas. As expected, this correction seems to be especially drastic for the lowest model layers and for areas outside the strongest meteorological anomalies, while more reasonable results are achieved higher up in the boundary layer and free troposphere over locations in the area affected by the heat wave such as Frankfurt. As a consequence of the change that can be expected from the reduced water stress, the magnitude 

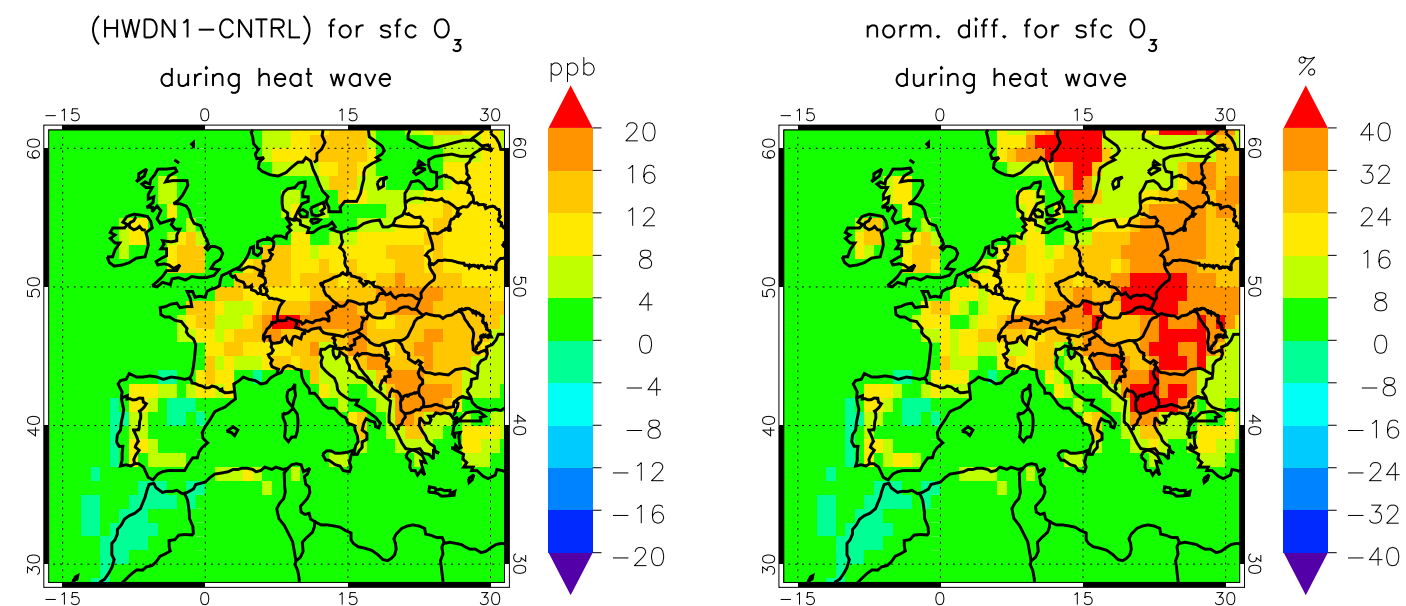

Fig. 12. Absolute and percentage differences for surface $\mathrm{O}_{3}$ resulting from the increase in stomatal resistance when setting the soil water stress to 0.1 (TM5-HWDN) compared to the reference run (TM5-HWHR). The normalised differences are given by Eq. (3).

of the negative $\mathrm{O}_{3}$ biases of TM5 with respect to MOZAIC measurements above Frankfurt decreases mainly in the PBL but also in the free troposphere (e.g. see $\sim 15 \%$ units of bias reduction for TM5-HWDN compared to TM5-HWHR in the PBL during the heat wave, Fig. 10 left). The biases become less negative than with a $25 \%$ increase in European anthropogenic emission (TM5-HWEE), and the difference in the bias for TM5-HWDN and the reference run (TM5-HWHR) is smaller than what is suggested in Fig. 12, where only the lowest model level is considered.

Over Western Europe, ozone concentrations in the PBL are still underestimated during the heat wave period, but overestimated before and particularly afterwards, under the assumption of ws $=0.1$. It is important to bear in mind the sudden decrease in ozone levels just after the heat wave period and the moderate ozone levels during 16-31 August (Fig. 4), when the soil wetness has not completely recovered (Fig. 11). Moreover, stomata in the leaves should react slowly to changes in soil wetness. As a consequence, other mechanisms remain to play an important role to explain the large $\mathrm{O}_{3}$ concentrations during the heat wave.

\subsection{Chemistry and dry deposition of ozone in MOCAGE}

The reasons for the ozone overestimation in MOCAGE are now discussed because the behaviour of this model contrasts with that of the MOZART and TM5 simulations. Net chemistry tendencies of ozone over the PBL and dry deposition velocities of ozone were compared between MOCAGE and the TM5 run with zoom to $1^{\circ} \times 1^{\circ}$ (TM5-HWHR) for the locations of the MOZAIC airports and for some grid cells over the Mediterranean during a period around the first fortnight of August 2003. In the case of the MOZAIC airports, this analysis revealed higher net chemical ozone production in MOCAGE than in TM5 at daytime (e.g. $0.7 \mathrm{ppb} / \mathrm{h}$ higher for Paris, $1.7 \mathrm{ppb} / \mathrm{h}$ higher for Vienna and $2 \mathrm{ppb} / \mathrm{h}$ higher for Frankfurt at $950 \mathrm{hPa}$ ) and lower dry deposition of ozone in MOCAGE at daytime (3-h dry deposition velocities are of around $0.1-1.1 \mathrm{~cm} / \mathrm{s}$ for TM5 and $0.2-0.6 \mathrm{~cm} / \mathrm{s}$ for MOCAGE, with the low values being registered at night and the high ones at daytime). The higher net chemical production and lower sink by dry deposition at daytime seem to explain at least part of the overestimation of ozone in MOCAGE, although other processes not sufficiently well represented in the model may also play a role. For the locations in the Mediterranean, net chemistry tendencies of $\mathrm{O}_{3}$ at daytime in the PBL are $0-0.4 \mathrm{ppb} / \mathrm{h}$ higher in MOCAGE than in TM5-HWHR, while dry deposition velocities are very small for both models (lower than $0.05 \mathrm{~cm} / \mathrm{s}$ ) and around $10 \%$ higher in TM5. The somewhat higher reactivity and lower dry deposition velocities in MOCAGE over these Mediterranean locations might not be enough to explain the high surface ozone modelled by MOCAGE over sea. The interpretation of these latest results is difficult because the ozone changes due to different sources (e.g. generally chemistry at daytime) and sinks (e.g. dry deposition) are smaller over sea than over land. In addition, even when the three CTMs use the same meteorological forcings and have thus similar vertical profiles for key meteorological variables (not shown), the different parameterisations of vertical diffusion (see Table 1) can have an impact on trace gas mixing ratios close to surface.

Concerning the higher net ozone production found for MOCAGE, it is worth to mention that the Regional Atmospheric Chemistry Mechanism (RACM) (Stockwell et al., 1997) used in this model includes a much larger number of reactions for VOC oxidation than the mechanisms used by the other two models. Even though MOZART and TM5 neglect to some extent some reactive species or groups of species included in RACM, their chemistry schemes have 

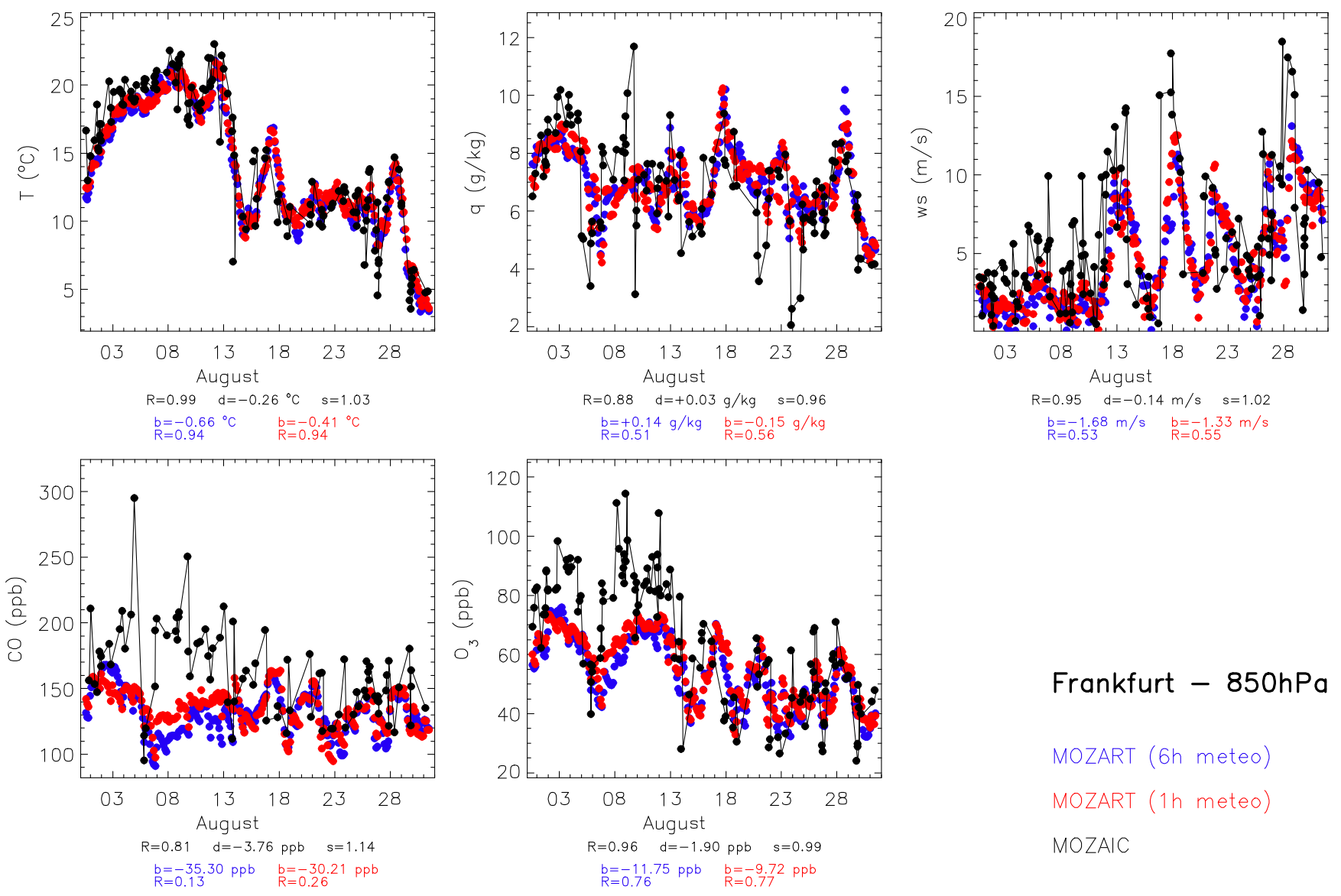

Frankfurt - 850hPa

MOZART (6h meteo)

MOZART ( $1 \mathrm{~h}$ meteo)

MOZAIC

Fig. 13. Evolution of modelled and measured temperature $(T)$, specific humidity $(q)$, wind speed (ws), carbon monoxide (CO) and ozone $\left(\mathrm{O}_{3}\right)$ at $850 \mathrm{hPa}$ above Frankfurt during August 2003 (both daytime and nighttime data are shown). MOZAIC measurements in black, base stand-alone MOZART simulation with $6 \mathrm{~h}$ meteorological feedback in blue and MOZART simulation with $1 \mathrm{~h}$ meteorological feedback (MOZART $1 \mathrm{~h}$-met) in red. $R, d$ and $s$ (in black) represent the correlation, average difference and ratio of standard deviations between time series of 3-h fields from both models. $b$ and $R$ represent mean bias and correlation with MOZAIC measurements for both MOZART runs (blue and red for runs with $6 \mathrm{~h}$ and $1 \mathrm{~h}$ meteorological input, respectively).

been adapted for describing ozone chemistry for the relatively coarse scale at which they run, with no objective to simulate fast reactive plumes which occur at sub-grid scale. On the contrary, the more comprehensive RACM mechanism was developed for regional air quality applications and is able to realistically reproduce fast ozone production in the outflow of polluted areas. The performance obtained in particular with MOCAGE for ozone at $0.1^{\circ} \times 0.1^{\circ}$ horizontal resolution is satisfactory, as described for instance in Dufour et al. (2004). The tendency to overestimate ozone in coarse resolution models is well documented (e.g. Liang and Jacobson, 2000). This is in link with the fact that dilution affects the simulated chemical regime, as a consequence of the non-linearities of the ozone/ $\mathrm{NO}_{\mathrm{x}} / \mathrm{VOC}$ system. This effect is more marked as the chemical scheme includes more reactive VOCs, which increase the non-linearities and the ozone production/destruction velocities. The excessively active photochemistry - high ozone, $\mathrm{OH}$ and oxidation of
VOCs - in MOCAGE has also been discussed in Bousserez et al. (2007), although running at $0.5^{\circ} \times 0.5^{\circ}$ resolution. It appears that a specific parameterisation of segregation effects (Esler, 2003) or a plume-in-grid approach is currently missing in MOCAGE for horizontal resolutions of $0.5^{\circ} \times 0.5^{\circ}$ and above.

Three sensitivity simulations (MOCAGE-STD, MOCAGE-VOCUT and MOCAGE-CUTALL, see description in Sect. 2.1.1 and Table 2) were performed to examine the impact of the initial conditions and the very comprehensive chemistry scheme used in MOCAGE. At $850 \mathrm{hPa}$ above Frankfurt, the change in the initial conditions in the MOCAGE-STD run leads to a strong ozone reduction of up to $20 \mathrm{ppb}$ on the first days but this simulation gets very close to the MOCAGE base run after around a month. This run reduces the fractional gross error in $\mathrm{O}_{3}$ from $27.6 \%$ to $21.3 \%$ and the modified normalised mean bias from $26.2 \%$ to $16.1 \%$ with respect to the MOCAGE base run during 
the period 16 July-15 August 2003 (only daytime data, i.e. 09:00-18:00 UTC, are considered for these calculations). The MOCAGE-VOCUT simulation reduces the fractional gross error and the modified normalised mean bias to $17.6 \%$ and $9.3 \%$, while MOCAGE-CUTALL reduces the same statistics to $16.1 \%$ and $-0.3 \%$, respectively. Similar results were found for Paris and Vienna. Results from the MOCAGE-STD and MOCAGE-CUTALL simulations also indicate that a sustained reduction of around $10 \mathrm{ppb}$ ozone can be achieved over the Mediterranean for the whole period when different initial conditions with lower tropospheric background $\mathrm{O}_{3}$ are used, which might be due to the lack of a strong ozone sink (e.g. dry deposition is small over sea), and that an additional $10 \mathrm{ppb}$ decrease is also gained when VOC emissions are strongly reduced. These sensitivity simulations, in particular the extreme MOCAGE-CUTALL, are not necessarily realistic and lead to a higher reduction of the biases than of the fractional gross errors for the location of the MOZAIC airports. However these results indicate that large part of the differences in the simulation of $\mathrm{O}_{3}$ by different models can be attributed to the way VOCs are treated and to some extent to differences in emissions datasets. As mentioned above, other processes such as the removal of ozone by dry deposition induce further uncertainty in the modelling of near-surface ozone.

\subsection{Frequency of the meteorological feedback}

To test the impact of the time resolution of the meteorological feedback used in the CTMs we have compared output fields from two MOZART simulations with similar configuration: the MOZART stand-alone run (6-h meteorological feedback) and a MOZART forecast run with 1-h meteorological feedback (MOZART 1h-met). Temperature, specific humidity, wind speed, $\mathrm{CO}$ and ozone from these simulations have been compared to MOZAIC measurements in the proximity of the PBL above Frankfurt, Paris and Vienna during August 2003 (both daytime and nighttime data have been used here). As an example, 3-h fields from both model simulations and MOZAIC observations at $850 \mathrm{hPa}$ above Frankfurt are shown in Fig. 13. Overall, the very similar results found for all airports suggest that the 6-h meteorological feedback and subsequent hourly interpolations used in two of the CTMs do not have a very large impact on the simulation of $\mathrm{O}_{3}$ and $\mathrm{CO}$. However hourly meteorological input generally improves the correlation of modelled meteorological parameters and chemical tracers with measurements and also reduces biases for $\mathrm{O}_{3}$ and $\mathrm{CO}$. The different parameterisations of transport - vertical turbulent tracer flux in the PBL (diffusion), convection, and advection - and chemistry used are expected to contribute more than the time interpolations to the differences found among the CTMs.

\section{Conclusions}

Three reference CTM stand-alone simulations performed with TM5, MOZART and MOCAGE, some sensitivity runs carried out with these models as well as two reanalysis simulations with the coupled IFS/MOZART system have been compared with European surface observations and vertical profiles from MOZAIC ascents/descents for three periods during summer 2003: before the heat wave (16-31 July 2003), during the heat wave (2-14 Aug 2003) and after the heat wave (16-31 Aug 2003). The strongest meteorological anomalies and the highest pollutant mixing ratios were found during the heat wave period.

The following conclusions can be drawn from the reference CTM stand-alone runs and the reanalysis runs:

- The meteorological analysis driving the three global CTMs (MOCAGE, MOZART and TM5) reproduces well the meteorological features during the period of study. The evolution of the $\mathrm{O}_{3}$ and $\mathrm{CO}$ mixing ratios is well simulated but these models tend to underestimate the actual pollution levels, particularly in the lower troposphere during the heat wave period.

- From all the simulations analysed, only MOCAGE overestimates the measured ozone mixing ratios. The reasons for this are partly related to the high net ozone production in this model, which uses a more explicit chemistry scheme (RACM) than the other models. Due to the relatively coarse resolution that can be afforded for global scale modelling, such a comprehensive chemistry scheme might introduce a positive bias that could be countered for instance by means of a plume-in-grid approach or of a parameterisation of segregation effects. In addition, the small removal of ozone by dry deposition at daytime in this model cannot compensate for the high net ozone production and therefore contributes to the overestimation of ozone.

- Lack of improvement in the modelling of $\mathrm{O}_{3}$ with the coupling (coupled MOZART/IFS run, COUPL) compared to the MOZART stand-alone run, with the exception of the lower levels during the heat wave. This points to the importance of small-scale ozone chemistry which cannot be resolved with the current resolutions of global CTMs (Wild and Prather, 2006), although this might not be the only reason why no overall improvement was achieved. The differences between the two coupled runs without (COUPL) and with (COUPLASSIM) satellite data assimilation are also small, probably because of the reduced sensitivity of satellite UV measurements to $\mathrm{O}_{3}$ absorption within the troposphere.

- The model simulations presented here cannot fully capture the impact of transport of pollution from Portuguese fires on air quality in Northern Europe. 
Emission inventories of forest fires at high temporal resolution as well as parameterisations of injection heights are needed in global CTMs to deliver relevant initial and boundary conditions for regional air quality models. This is particularly important for modelling large scale heat waves, which are often associated with biomass fires.

- TM5 has difficulties in reproducing the measured CO mixing ratios. This is a result of the underrepresentation of biogenic and biomass burning $\mathrm{CO}$ emissions, methane and some higher hydrocarbons in the reference TM5 runs used here.

- Lower CO biases are found for the coupled IFS/MOZART run (COUPL) compared to the base MOZART stand-alone run. Since the chemistry in the coupled system is the same as in the MOZART runs, the improved results might be due both to improvements in the meteorology (full meteorological modelling in IFS compared to the only 6-h meteorological feedback in MOZART) and better treatment of transport process in IFS. In addition, the assimilation of $\mathrm{CO}$ columns from MOPITT (COUPL-ASSIM run) further improves the comparisons with MOZAIC data, reducing negative biases to less than $20 \%$ for all tropospheric levels and periods with the exception of the PBL above Frankfurt during the heat wave. Therefore, the assimilation efficiently overcomes some of the deficiencies in the transport, chemistry or emissions in the model.

Conclusions from the sensitivity runs:

- Results from the high resolution MOZART run (MOZART t106) suggest that the coarse resolution of the global CTMs is one of the causes of the differences with the observations. A better simulation of the horizontal/vertical transport with the increased resolution in MOZART is likely to be responsible for the enhanced accumulation of pollution within the lowest levels in this run.

- The TM5 simulations with increased emissions in Europe (HWEE) and no anthropogenic emissions outside Europe (HWEN) indicate that uncertainties in European emissions and in long-range transport in the models have a limited effect and cannot completely account for the underestimation of $\mathrm{CO}$ and $\mathrm{O}_{3}$ by the models.

- The TM5 sensitivity run with reduced soil water stress (HWDN) leads to the strongest reduction in the negative $\mathrm{O}_{3}$ biases but still underestimates ozone concentrations in the PBL during the heat wave period. Low dry deposition as a consequence of the dryness of vegetation is likely to have contributed to the elevated levels of both ozone and some other species found for this period.
- Results from two MOCAGE sensitivity runs (MOCAGE-VOCUT and MOCAGE-CUTALL) indicate that large part of the differences in the simulation of $\mathrm{O}_{3}$ by different models can be attributed to the way VOCs are treated in the chemistry scheme and to some extent to differences in emissions datasets.

- The increase in the frequency of the meteorological feedback into the CTMs from 6-h (e.g. MOZART standalone run) to 1-h (e.g. MOZART $1 \mathrm{~h}$-met) does not seem to lead to a large improvement in the modelling of $\mathrm{O}_{3}$ and $\mathrm{CO}$. The different parameterisations of transport and chemistry used are expected to contribute more than the time interpolations to the differences found among the CTMs.

The factors and processes mentioned here (horizontal resolution, European emissions, long-range transport, influence of the soil water stress on surface dry deposition, and chemistry schemes) have a significant impact on the simulation of pollution during the heat wave period. However other mechanisms remain to play an important role to explain the high $\mathrm{O}_{3}$ concentrations during the heat wave:

- Some of the mechanisms that might be underrepresented by the models are horizontal/vertical transport such as ventilation of the PBL and entrainment of polluted air from the residual layer into the PBL (e.g. Lee et al., 2006), or the time resolution of anthropogenic emissions (monthly emissions are used and therefore daily and monthly cycles are not included). Moreover, the model simulations analysed here have not considered the effect of high temperatures on the biogenic emissions (e.g. Lee et al., 2006; Solberg et al., 2008) and on the evaporation of anthropogenic VOCs (e.g. Vautard et al., 2005), which together with moderately high $\mathrm{NO}_{\mathrm{x}}$ concentrations can increase $\mathrm{O}_{3}$ production. The decrease in photolysis rates and subsequent inhibition of regional ozone production as well as the reinforcement of atmospheric stability caused by the presence of elevated smoke layers from biomass burning over Europe during this period (Hodzic et al., 2007) have not been considered in the model simulations presented here either.

- The different magnitude and even different sign of the $\mathrm{O}_{3}$ biases found for Frankfurt, Paris and Vienna within the PBL outside the heat wave period may be related to the representativity of these airports for the regions covered by the CTM grids. Some local effects in the vicinity of these airports, particularly in the lower tropospheric levels, are likely to be partly responsible for those differences. In addition, ascents and descents extend horizontally within $300-400 \mathrm{~km}$ and are performed in certain directions from the airports. This "horizontal position bias" with regard to the airport location is the largest for the upper part of the profiles. 
The model runs analysed here have coarse horizontal resolution, and all of them use monthly emissions at $1^{\circ} \times 1^{\circ}$ horizontal resolution which have been smoothed to the size of the corresponding model grid cells. This surely has an impact on the recirculation and accumulation of pollution within the boundary layer, and therefore in the chemistry and in the ozone levels over Central/Western Europe during and outside the heat wave period. The meteorological and photochemical modelling of such an extreme episode requires higher spatial resolution and finer temporally resolved emission data. The development of the global CTMs and coupled system presented here is not aimed at achieving such good performances that enable them to be compared on an absolute basis with surface measurements in extreme cases such as the 2003 European heat wave. In this context global models should be judged by their ability to provide reasonable simulations in the troposphere that can be used by fine scale regional air quality models which have more comprehensive VOC oxidation schemes. In this paper we have focussed on the vertical profiles of $\mathrm{CO}$ and $\mathrm{O}_{3}$ over Europe in the mentioned period. One of the final objectives of the development of a coupled system is to provide forcing fields (initialisation and lateral boundary conditions) that include incipient signatures of anomalies to regional air quality models on a daily basis. This is currently being done very satisfactorily within the GRG (Global Reactive Gases) sub-project of GEMS, which is bound for the RAQ (Regional Air Quality) sub-project and also provides initial and boundary conditions for other European models. A number of regional CTM simulations of summer 2003 have been performed within GEMS-RAQ using different chemical boundary conditions (Rouil et al., 2010). That publication will serve as an example of the relevance of the boundary conditions and usefulness of the coupled system presented here.

Acknowledgements. GEMS was funded by the European Commission under the EU Sixth Research Framework Programme, contract number SIP4-CT-2004-516099. The authors acknowledge the strong support of the European Commission, Airbus and airlines - Lufthansa, Air France, Austrian and former Sabena - to the MOZAIC program. We also thank the EMEP and GAW programs for the careful work done in obtaining the surface data used in this study. We are indebted to the initiator and coordinator of the GEMS project, Anthony Hollingsworth, who sadly passed away on 29 July 2007.

Edited by: B. N. Duncan

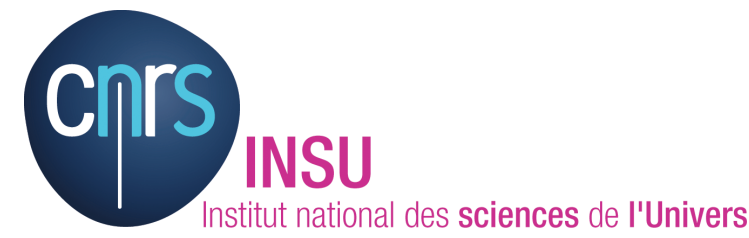

The publication of this article is financed by CNRS-INSU.

\section{References}

Aas, W., and Hjellbrekke, A-G.: Data quality 2003, quality assurance and field comparisons, EMEP/CCC-Report 6/2005, Reference O-95024, Norwegian Institute for Air Research, Kjeller, 2005.

Agnew, P., Mittermaier, M. P., Honore, C., Elbern, H., Coll, I., Vautard, R., and Peuch, V.-H.: Evaluation of GEMS Regional Air Quality Forecasts, GEMS report, available at http://gems.ecmwf. int/do/get/PublicDocuments/1533/1402?showfile=true, 2007.

Bechtold, P., Bazile, E., Guichard, F., Mascart, P., and Richard, E.: A mass flux convection scheme for regional and global models, Q. J. R. Meteorol. Soc., 127, 869-886, 2001.

Beer, R., Glavich, T. A., and Rider, D. M.: Tropospheric Emission Spectrometer for the Earth Observing System's Aura satellite, Appl. Optics, 40, 2356-2367, 2001.

Beniston, M.: The 2003 heat wave in Europe - A shape of things to come? An analysis based on Swiss climatological data and model simulations, Geophys. Res. Lett., 31, L02202, doi:10.1029/2003GL018857, 2004.

Bousserez, N., Attié, J.-L., Peuch, V.-H., Michou, M., Pfister, G., et al.: Evaluation of the MOCAGE chemistry and transport model during the ICARTT/ITOP experiment, J. Geophys. Res., 112, D10S42, doi:10.1029/2006JD007595, 2007.

Bowman, K. W., Worden, J., Steck, T., Worden, H. M., Clough, S., and Rodgers, C. D.: Capturing time and vertical variability of tropospheric ozone: A study using TES nadir retrievals, J. Geophys. Res., 107(D23), 4723, doi:10.1029/2002JD002150, 2002.

Dufour, A., Amodei, M., Ancellet, G., and Peuch, V.-H.: Observed and modelled "chemical weather" during ESCOMPTE, Atmos. Res., 74(1-4), 161-189, 2004.

Eremenko, M., Dufour, G., Foret, G., Keim, C., Orphal, J., Beekmann, M., Bergametti, G., and Flaud, J.-M.: Tropospheric ozone distributions over Europe during the heat wave in July 2007 observed from infrared Nadir spectra measured by IASI, Geophys. Res. Lett., 35, L18805, doi:10.1029/2008GL034803, 2008.

Esler, J. G.: An integrated approach to mixing sensitivities in tropospheric chemistry: A basis for the parameterization of subgridscale emissions for chemistry transport models, J. Geophys. Res., 108(D20), 4632, doi:10.1029/2003JD003627, 2003.

Fiala, J., Cernikovsky, L., de Leeuw, F., and Kurfuerst, P.: Air pollution by ozone in Europe in summer 2003 - Overview of exceedances of EC ozone threshold values during the summer season April-August 2003 and comparisons with previous years, EEA Topic Report No. 3/2003, European Environment Agency, Copenhagen, 2003.

Filleul, L., Cassadou, S., Médina, S., Fabres, P., Lefranc, A., Eilstein, D., Le Tertre, A., Pascal, L., Chardon, B., Blanchard, M., Declercq, C., Jusot, J.-F., Prouvost, H., and Ledrans, M.: The relation between temperature, ozone and mortality in nine French 
cities during the heat wave of 2003, Environ. Health Perspect., 114(9), 1344-1347, 2006.

Fischer, P. H., Brunekreef, B., and Lebret, E.: Air pollution related deaths during the 2003 heat wave in the Netherlands, Atmos. Environ., 38, 1083-1085, 2004.

Flemming, J., Inness, A., Flentje, H., Huijnen, V., Moinat, P., Schultz, M. G., and Stein, O.: Coupling global chemistry transport models to ECMWF's integrated forecast system, Geosci. Model Dev., 2, 253-265, 2009.

Ganzeveld, L., Lelieveld, J., and Roelofs, G.-J.: A dry deposition parameterization for sulfur oxides in a chemistry and general circulation model, J. Geophys. Res., 103(D5), 5679-5694, doi:10.1029/97JD03077, 1998.

Gardner, R. M., Adams, K., Cook, T., Deidewig, F., Ernedal, S., Falk, R., Fleuti, E., Herms, E., Johnson, C. E., Lecht, M., Lee, D. S., Leech, M., Lister, D., Masse, B., Metcalfe, M., Newton, P., Schmitt, A., Vandenbergh, C., and Van Drimmelen, R.: The ANCAT/EC global inventory of $\mathrm{NO}_{\mathrm{x}}$ emissions from aircraft, Atmos. Environ., 31(12), 1751-1766, 1997.

Giorgi, F. and Chameides, W. L.: Rainout lifetimes of highly soluble aerosols and gases as inferred from simulations with a general circulation model, J. Geophys. Res., 91, 14367-14376, 1986.

Guelle, W., Balkanski, Y. J., Schulz, M., Dulac, F., and Monfray, P.: Wet deposition in a global size-dependent aerosol transport model 1 , Comparison of a 1 year $\mathrm{Pb}$ simulation with ground measurements, J. Geophys. Res., 103(D10), 1142911445, doi:10.1029/97JD03680, 1998.

Guerova, G., and Jones, N.: A global model study of ozone enhancement during the August 2003 heat wave in Europe, Environ. Chem., 4(5), 285-292, doi:10.1071/EN07027, 2007.

Hack, J. J: Parameterization of moist convection in the National Center for Atmospheric Research community climate model (CCM2), J. Geophys. Res., 99(D3), 5551-5568, 1994.

Hjellbrekke, A.-G. and Solberg, S.: Ozone Measurements 2003, EMEP/CCC Report 4/2005, Reference O-99074, Norwegian Institute for Air Research, Kjeller, 2005.

Hodzic, A., Vautard, R., Chepfer, H., Goloub, P., Menut, L., Chazette, P., Deuzé, J. L., Apituley, A., and Couvert, P.: Evolution of aerosol optical thickness over Europe during the August 2003 heat wave as seen from CHIMERE model simulations and POLDER data, Atmos. Chem. Phys., 6, 1853-1864, 2006, http://www.atmos-chem-phys.net/6/1853/2006/.

Hodzic, A., Madronich, S., Bohn, B., Massie, S., Menut, L., and Wiedinmyer, C.: Wildfire particulate matter in Europe during summer 2003 - meso-scale modeling of smoke emissions, transport and radiative effects, Atmos. Chem. Phys., 7, 40434064, 2007.

Hollingsworth, A., Engelen, R. J., Textor, C., Benedetti, A., Boucher, O., et al.: The Global Earth-system Monitoring using Satellite and in-situ data (GEMS) Project: Towards a monitoring and forecasting system for atmospheric composition, BAMS, 89(8), 1147-1164, doi:10.1175/2008BAMS2355.1, 2008.

Holtslag, A. A. M. and Boville, B. A.: Local versus nonlocal boundary-layer diffusion in a global climate model, J. Climate, 6 (10), 1825-1842, 1993.

Holtslag, A. A. M. and Moeng, C.-H.: Eddy diffusivity and countergradient transport in the convective atmospheric boundary layer, J. Atmos. Sci., 48(14), 1690-1698, 1991.

Horowitz, L. W., Walters, S., Mauzerall, D. L., Emmons, L. K.,
Rasch, P. J., Granier, C., Tie, X., Lamarque, J.-F., Schultz, M. G., Tyndall, G. S., Orlando, J. J., and Brasseur, G. P.: A global simulation of tropospheric ozone and related tracers: Description and evaluation of MOZART, version 2, J. Geophys. Res., 108(D24), 4784, doi:10.1029/2002JD002853, 2003.

Houweling, S., Dentener, F., and Lelieveld, J.: The impact of non-methane hydrocarbon compounds on tropospheric photochemistry, J. Geophys. Res., 103(D9), 10673-10696, doi:10.1029/97JD03582, 1998.

Inness, A., Flemming, J., Suttie, M., and Jones, L.: GEMS data assimilation system for chemically reactive gases, ECMWF Technical Memorandum 587, European Centre for Medium-Range Weather Forecast, Reading, available at: http://www.ecmwf.int/publications/library/ecpublications/_ $\mathrm{pdf} / \mathrm{tm} / 501-600 / \mathrm{tm} 587 . p d f, 2009$.

Josse, B., Simon, P., and Peuch, V.-H.: Radon global simulations with the multiscale chemistry and transport model MOCAGE, Tellus B, 56(4), 339-356, 2004.

Kinnison, D. E., Brasseur, G. P., Walters, S., Garcia, R. R., Marsh, D. R., Sassi, F., Harvey, V. L., Randall, C. E., Emmons, L., Lamarque, J. F., Hess, P., Orlando, J. J., Tie, X. X., Randel, W. , Pan, L. L., Gettelman, A., Granier, C., Diehl, T., Niemeier, U., and Simmons, A. J.: Sensitivity of Chemical Tracers to Meteorological Parameters in the MOZART3 Chemical Transport Model, J. Geophys. Res, 112, D20302, doi:10.1029/2006JD007879, 2007.

Krol, M., Houweling, S., Bregman, B., van den Broek, M., Segers, A., van Velthoven, P., Peters, W., Dentener, F., and Bergamaschi, P.: The two-way nested chemistry-transport zoom model TM5: Algoritm and Applications, Atmos. Chem. Phys., 5(2), 417-432, 2005.

Lathière, J., Hauglustaine, D. A., De Noblet-Ducoudré, N., Krinner, G., and Folberth, G. A.: Past and future changes in biogenic volatile organic compound emissions simulated with a global dynamic vegetation model, Geophys. Res. Lett., 32, L20818, doi:10.1029/2005GL024164, 2005.

Lee, J. D., Lewis, A. C., Monks, P. S., et al.: Ozone photochemistry and elevated isoprene during the UK heatwave of August 2003, Atmos. Environ., 40, 7598-7613, 2006.

Lefèvre, F., Brasseur, G. P., Folkins, I., Smith, A. K., and Simon, P.: Chemistry of the 1991-1992 stratospheric winter - Three dimensional model simulations, J. Geophys. Res., 99(D4), 8183-8195, 1994.

Liang, J. and Jacobson, M. Z.: Effects of subgrid segregation on ozone production efficiency in a chemical model, Atmos. Environ., 34, 2975-2982, 2000.

Lin, S. J. and Rood, R. B.: Multidimensinal flux-form semiLagrangian transport schemes, Mon. Weather. Rev., 124, 20462070, 1996.

Louis, J. F.: A parametric model of vertical eddy fluxes in the atmosphere, Boundary Lay. Meteorol., 17, 187-202, 1979.

Luterbacher, J., Dietrich, D., Xoplaki, E., Grosjean, M., and Wanner, H.: European seasonal and annual temperature variability, trends, and extremes since 1500, Science, 303, 1499-1503, 2004.

Madronich, S., and Flocke, S.: The role of solar radiation in atmospheric chemistry, in Handbook of Environmental Chemistry, edited by P. Boule, Springer-Verlag, New York, USA, 1-26, 1998.

Marenco, A., Thouret, V., Nédélec, P., Smit, H., Helten, M., Kley, 
D., Karcher, F., Simon, P., Law, K., Pyle, J., Poschmann, G., Von Wrede, R., Hume, C., and Cook, T.: Measurement of ozone and water vapour by Airbus in-service aircraft: The MOZAIC airborne program, An overview, J. Geophys. Res., 103(D19), 25631-25642, doi:10.1029/98JD00977, 1998.

Mari, C., Jacob, D. J., and Bechtold, P.: Transport and scavenging of soluble gases in a deep convective cloud, J. Geophys. Res., 105, 22255-22267, 2000.

Michou, M. and Peuch, V.-H.: Surface exchanges in the MOCAGE multi-scale chemistry and transport model, J. Water Sci., 15, 173-204, 2002.

Michou, M., Laville, P., Serça, D., Fotiadi, A., Bouchou, P., and Peuch, V.-H.: Measured and modeled dry deposition velocities over the ESCOMPTE area, Atmos. Res., 74(1-4), 89-116, 2004.

Müller, J.-F.: Geographical distribution and seasonal variation of surface emissions and deposition velocities of atmospheric trace gases, J. Geophys. Res., 97, 3787-3804, 1992.

Nedelec, P., Cammas, J. P., Thouret, V., Athier, G., Cousin, J. M., Legrand, C., Abonnel, C., Lecoeur, F., Cayez, G., and Marizy, C.: An improved infrared carbon monoxide analyser for routine measurements aboard commercial Airbus aircraft: technical validation and first scientific results of the MOZAIC III programme, Atmos. Chem. Phys., 3, 1551-1564, 2003, http://www.atmos-chem-phys.net/3/1551/2003/.

Ordóñez, C., Mathis, H., Furger, M., Henne, S., Hüglin, C., Staehelin, J., and Prévôt, A. S. H.: Changes of daily surface ozone maxima in Switzerland in all seasons from 1992 to 2002 and discussion of summer 2003, Atmos. Chem. Phys., 5, 1187-1203, 2005, http://www.atmos-chem-phys.net/5/1187/2005/.

Prather, M.: Numerical advection by conservation of second-order moments, J. Geophys. Res., 91, 6671-6681, 1986.

Rabier, F., Järvinen, H., Klinker, E., Mahfouf, J.-F., and Simmons, A.: The ECMWF operational implementation of fourdimensional variational assimilation. Part I: Experimental results with simplified physics, Q. J. Roy. Meteor. Soc., 126 (564), 1143-1170, 2000.

Randerson, J. T., van der Werf, G. R., Collatz, G. J., Giglio, L., Still, C. J., Kasibhatla, P., Miller, J. B., White, J. W. C., DeFries, R. S., and Kasischke, E. S.: Fire emissions from $\mathrm{C}_{3}$ and $\mathrm{C}_{4}$ vegetation and their influence on interannual variability of atmospheric $\mathrm{CO}_{2}$ and $\delta^{13} \mathrm{CO}_{2}$, Global Biogeochem. Cy., 19, GB2019, doi:10.1029/2004GB002366, 2005.

Randerson, J. T., van der Werf, G. R., Giglio, L., Collatz, G. J., and Kasibhatla, P. S.: Global Fire Emissions Database, Version 2 (GFEDv2.1), data set, available online at: http://daac.ornl.gov/ from Oak Ridge National Laboratory Distributed Active Archive Center, Oak Ridge, Tennessee, USA, 2007.

Redler, R., Valcke, S., and Ritzdorf, H.: OASIS4 - a coupling software for next generation earth system modelling, Geosci. Model Dev. Discuss., 2, 797-843, 2009.

Rouil, L., Tarrason, L., Peuch, V.-H., et al.: Impact of the 2003 heatwave in Western Europe on air quality: new insights from the GEMS multi-model system, Atmos. Chem. Phys., in preparation, 2010.

Russell, G. L. and Lerner, J. A.: A new finite-differencing scheme for the tracer transport equation, J. Appl. Meteorol., 20, 14831498, 1981

Schär, C., Vidale, P. L., Lüthi, D., Frei, C., Häberli, C., Liniger, M. A., and Appenzeller, C.: The role of increasing temperature variability in European summer heatwaves, Nature, 427, 332 336, 2004.

Schmitt, A. and Brunner, B: Emissions from aviation and their development over time, in Final Report on the BMBF Verbundprogramm, Schadstoffe in der Luftfahrt, edited by: Schumann, U., Chlond, A., Ebel, A., Karcher, B., Pak, H., Schlager, H., Schmitt, A., and Wendling, P., DLR Mitteilung 97-04, Köln, 1997.

Solberg, S., Hov, Ø., Søvde, A., Isaksen, I. S. A., Coddeville, P., De Backer, H., Forster, C., Orsolini, Y., and Uhse, K.: European surface ozone in the extreme summer 2003, J. Geophys. Res., 113, D07307, doi:10.1029/2007JD009098, 2008.

Stedman, J. R.: The predicted number of air pollution related deaths in the UK during the August 2003 heatwave, Atmos. Environ., 38, 1087-1090, 2004.

Stockwell, W., Kirchner, F., Kuhn, M., and Seefeld, S.: A new mechanism for regional atmospheric chemistry modelling, J. Geophys. Res., 102(D22), 25847-25879, 1997.

Stott, P. A., Stone, D. A., and Allen, M. R.: Human contribution to the European heatwave of 2003, Nature, 432, 610-614, doi:10.1038/nature03089, 2004.

Thouret, V., Marenco, A., Logan, J. A., Nédélec, P., and Grouhel, C.: Comparisons of ozone measurements from the MOZAIC airborne program and the ozone sounding network at eight locations, J. Geophys. Res., 103(D19), 25695-25720, doi:10.1029/98JD02243, 1998.

Tiedtke, M.: A comprehensive mass flux scheme for cumulus parametrisation in large-scale models, Mon. Weather Rev., 177, 1779-1800, 1989.

Tressol, M., Ordonez, C., Zbinden, R., Brioude, J., Thouret, V., Mari, C., Nédélec, P., Cammas, J.-P., Smit, H., Patz, H.-W., and Volz-Thomas, A.: Air pollution during the 2003 European heat wave as seen by MOZAIC airliners, Atmos. Chem. Phys., 8, 2133-2150, 2008, http://www.atmos-chem-phys.net/8/2133/2008/.

Trigo, R. M., García-Herrera, R., Díaz, J., Franco Trigo, I., and Valente, M. A.: How exceptional was the early August 2003 heatwave in France?, Geophys. Res. Lett., 32, L10701, doi:10.1029/2005GL022410, 2005.

Turquety, S., Hadji-Lazaro, J., Clerbaux, C., Hauglustaine, D. A., Clough, S. A., Cassé, V., Schlüssel, P., and Mégie, G.: Operational trace gas retrieval algorithm for the Infrared Atmospheric Sounding Interferometer, J. Geophys. Res., 109, D21301, doi:10.1029/2004JD004821, 2004.

Uppala, S. M., Kållberg, P. W., Simmons, A. J., et al.: The ERA-40 re-analysis, Q. J. Roy. Meteorol. Soc., 131, 2961-3012, doi:10.1256/qj.04.176, 2005.

van der Werf, G. R., Randerson, J. T., Giglio, L., Collatz, G. J., Kasibhatla, P. S., and Arellano Jr., A. F.: Interannual variability in global biomass burning emissions from 1997 to 2004, Atmos. Chem. Phys., 6, 3423-3441, 2006, http://www.atmos-chem-phys.net/6/3423/2006/.

Vautard, R., Honoré, C., Beekmann, M., and Rouil, L.: Simulation of ozone during the August 2003 heat wave and emission control scenarios, Atmos. Environ., 39, 2957-2967, 2005.

Volz-Thomas, A., Berg, M., Heil, T., Houben, N., Lerner, A., Petrick, W., Raak, D., and Pätz, H.-W.: Measurements of total odd nitrogen $\left(\mathrm{NO}_{\mathrm{y}}\right)$ aboard MOZAIC in-service aircraft: instrument design, operation and performance, Atmos. Chem. Phys., 5, 583595, 2005, http://www.atmos-chem-phys.net/5/583/2005/. 
Wesely, M. L.: Improved parameterizations for surface resistance to gaseous dry deposition in regional-scale numerical models, Atmos. Environ., 23, 1293-1304, 1989.

Wild, O. and Prather, M. J.: Global tropospheric ozone modeling: Quantifying errors due to grid resolution, J. Geophys. Res., 111, D11305, doi:10.1029/2005JD006605, 2006.

Williams, J. E., Landgraf, J., Bregman, A., and Walter, H. H.: A modified band approach for the accurate calculation of online photolysis rates in stratospheric-tropospheric chemistry transport models, Atmos. Chem. Phys., 6(12), 4137-4161, 2006.

Williamson, D. L. and Rasch, P. J.: Two-dimensional semilagrangian transport with shape-preserving interpolation, Mon. Weather Rev., 117, 102-129, 1989.
World Health Organization (WHO): Heat-waves: risks and responses, Health Global Environmental Change, No. 2, WHO Regional Office for Europe, Copenhagen, Denmark, 2004.

Zbinden, R. M., Cammas, J.-P., Thouret, V., Nédélec, P., Karcher, F., and Simon, P.: Mid-latitude tropospheric ozone columns from the MOZAIC program: climatology and interannual variability, Atmos. Chem. Phys., 6, 1053-1073, 2006, http://www.atmos-chem-phys.net/6/1053/2006/.

Zhang, G. J. and McFarlane, N. A.: Sensitivity of climate simulations to the parameterization of cumulus convection in the Canadian climate centre general circulation model, Atmos. Ocean., 33, 407-446, 1995. 